\title{
Isolation, Study and Application of Organosolv Lignins (Review)
}

\author{
Boris N. Kuznetsov*a, \\ Yuriy N. Malyara, Svetlana A. Kuznetsova ${ }^{a}$, \\ Lyudmila I. Grishechkoa, Alexander S. Kazachenko ${ }^{a}$, \\ Alexander V. Levdansky ${ }^{a}$, Andrey V. Pestunova \\ Anatoly N. Boyandin ${ }^{\mathrm{b}}$ and Alan Celzard \\ "Institute of Chemistry and Chemical Technology $S B R A S$ \\ FRC "Krasnoyarsk Science Center SB RAS" \\ 50/24 Akademgorodok, Krasnoyarsk, 660036, Russia \\ ${ }^{b}$ Institute of Biophysics SB RAS, \\ FRC "Krasnoyarsk Science Center SB RAS" \\ 50/50 Akademgorodok, Krasnoyarsk, 660036, Russia \\ ${ }^{c}$ Institut Jean Lamour, UMR CNRS - Universit'e de Lorraine \\ no. 7198. ENSTIB \\ 27 rue Philippe S'eguin, CS 60036, 88026 Epinal cedex, France
}

The analysis of the literature on the methods of soluble organosolv lignins isolation, their physicalchemical study and on the method of their processing to porous aerogels and liquid hydrocarbons was carried out. A review of the literature allowed us to choice of the most important areas of research. For isolation from wood the soluble lignins free from sulfur the methods of catalytic peroxide delignification at mild conditions (temperature $\leq 100{ }^{\circ} \mathrm{C}$, atmospheric pressure) and methods of lignin extraction by supercritical organic solvents were used.

Molecular mass and molecular-mass distribution of ethanol-lignin samples isolated from aspenwood and abies-wood were studied by gel-permeation chromatography. Weighted molecular mass of ethanol-lignin from abies wood is $478 \mathrm{Da}$ and that from aspen wood ethanol-lignin-750 Da. Thus, the studied samples of ethanol-lignin have rather low molecular mass, what should facilitate their further processing to liquid hydrocarbons and aerogels.

For the depolymerization of organosolv lignins to liquid hydrocarbons the processes of their catalytic conversion in supercritical alcohols have good prospects for the use. In the processes of lignin thermal conversion alcohols can to extract the products of lignin depolymerization and to alkylate these products, preventing their repolymerization to high molecular mass substances.

(C) Siberian Federal University. All rights reserved

* Corresponding author E-mail address: inm@icct.ru 
To obtain a new class of nanoporous materials based on lignin the methods of organic aerogels synthesis from mixtures of lignin with other natural polymers and crosslinking agents were applied. It was found that the structure and properties of porous materials of aerogel type depend not only from the reaction mixture composition but from the method of drying. Drying in subcritical conditions leads to the formation of xerogels, in supercritical conditions - to the formation aerogels and the freezdrying - of cryogels. Obtained porous materials can have very low density (around $0.2 \mathrm{~g} / \mathrm{cm}^{3}$ ), high specific surface area (to $500 \mathrm{~m}^{2} / \mathrm{g}$ ) and the pore volume near $5 \mathrm{~cm}^{3} / \mathrm{g}$.

Keywords: organosolv lignin, isolation, structure, catalytic depolymerization, molecular weight, application, liquid hydrocarbons, aerogels.

DOI: $10.17516 / 1998-2836-2016-9-4-454-482$.

\title{
Выделение, изучение и применение органосольвентных лигнинов (обзор)
}

\author{
Б.Н. Кузнецов ${ }^{\text {a }, ~ Ю . Н . ~ М а л я р ~}{ }^{a}$, С.А. Кузнецова ${ }^{a}$, \\ Л.И. Гришечко ${ }^{a}$, А.С. Казаченко \\ А.В. Пестунов ${ }^{\text {a }}$, А.Н. Бояндин ${ }^{6}$, А. Селзард ${ }^{\text {в }}$ \\ ${ }^{a}$ Институт химии и химической технологии СО РАН \\ ФИЦ «Красноярский научный иентр СО РАН» \\ Россия, 660036, Красноярск, Академгородок, 50/24 \\ ${ }^{6}$ Институт биофизики СО РАН \\ ФИЦ «Красноярский научный центр СО РАН» \\ Россия,660036, Красноярск, Академгородок 50/50 \\ ${ }^{\circ}$ Институт Жана Ламура \\ Университет Лотарингии \\ Франщия, 88026, Эпиналь, ул. Филипп Сеген, 27
}

Проведен анализ последних литературных источников, посвященных методам выделения растворимых органосольвентных лигнинов, их изучению физико-химическими методами и способам переработки в пористые аэрогели и жидкие углеводороды. Выполненный обзор литературы позволил обосновать выбор наиболее актуальных направлений исследований. Для выделения из древесины растворимых лигнинов, не содержащих серу, использованы методы каталитической пероксидной делигнификации в мягких условиях (температура $\leq 100{ }^{\circ} \mathrm{C}$, атмосферное давление) и методы экстракции сверхкритическими органическими растворителями.

Молекулярная масса и молекулярно-массовое распределение образиов этаноллигнина, выделенных из древесины осины и пихты, исследованы с помощью метода гель-проникающей хроматографии. Средневесовая молекулярная масса этаноллигнина пихты равна 478 Да, а 
этаноллигнина осинь - 750 Да. Таким образом, изученные образцы этаноллигнина имеют довольно низкую молекулярную массу, что должно облегчить их дальнейшую переработку в жидкие углеводороды и аэрогели.

Для деполимеризации органосольвентных лигнинов в жидкие углеводороды перспективно использовать прочессы их каталитической конверсии в сверхкритических низиих спиртах. В процессах термической конверсии лигнинов спирты не только экстрагируют продукть термической деполимеризации лигнина, но и способнь их алкилировать, предотвращая вторичные реакции образования высокомолекулярных веществ. Твердые кислотные катализаторы позволяют повысить конверсию лигнина и выход жидких углеводородов.

Для получения на основе лигнина нового класса нанопористых материалов использовань методы синтеза органических аэрогелей из смесей лигнина с другими природными полимерами и сшивающими агентами типа формальдегида. Установлено, что на строение и свойства пористых материалов аэрогельного типа оказывает влияние не только компонентный состав реакционной смеси, но и способ сушки. Сушка в докритических условиях приводит к образованию ксерогелей, в сверхкритических условиях - аэрогелей, лиофильная сушка криогелей. Полученные пористые материаль могут иметь очень низкую плотность (около

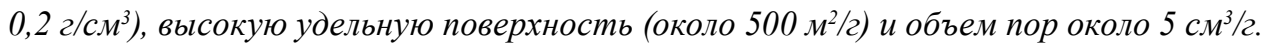

Ключевые слова: органосольвентные лигнины, выделение, структура, каталитическая деполимеризация, молекулярная масса, применение, жидкие углеводороды, аэрогели.

\section{Введение}

Лигнины - это природные фенольные макромолекулы, которые присутствуют в стенках растительных клеток, состоящих из трех основных фенилпропановых единиц, являющихся производными ароматических спиртов: $n$-кумарилового, кониферилового и синапилового [1]. Лигнин имеет весьма сложную аморфную структуру, состоящую из фенилпропановых фрагментов, хаотично сшитых между собой C-C- и C-O-связями. В растительных клетках лигнин функционирует в качестве биологического барьера и «клея» для связывания между собой гемицеллюлоз и целлюлозы [2].

Лигнин - крупнотоннажный отход целлюлозно-бумажной и гидролизной промышленности, причем ожидается, что количество лигнина значительно увеличится при запуске заводов по производству биоэтанола второго поколения [3]. Благодаря своей уникальной структуре лигнин имеет значительный потенциал для химической переработки в ценные продукты, в том числе для производства химикатов фенольной и ароматической природы, а также жидких топлив $[4,5]$.

Хотя лигнин имеет большой потенциал в качестве возобновляемого источника топлива и ароматических химических веществ, технологии его переработки значительно менее развиты, чем полисахаридов. Разработка технологий переработки лигнинов осложняется тем, что их состав весьма неоднороден и определяется не только природой исходного лигноцеллюлозного полимера, но и способами их выделения.

Существует несколько различных путей выделения лигнинов из биомассы, которые можно разделить на две основные группы. К одной из них относятся процессы деполимеризации 
лигнина на растворимые фрагменты, которые отделяют от целлюлозного продукта. К другой процессы гидролиза полисахаридов до растворимых сахаров, которые отделяют от твердого лигнина. Примером первой группы являются все процессы варки целлюлозы [6], а примером второй - гидролиз лигноцеллюлозного сырья с получением сахаров, фурфурола и левулиновой кислоты [7].

Независимо от используемого процесса лигнин обычно претерпевает значительные структурные изменения при отделении от других компонентов и, следовательно, реакционная способность выделенных лигнинов может существенно отличаться от таковой, характерной для нативного лигнина древесины.

Термин «органосольвентные процессы» относится к группе варочных процессов, основанных на использовании легкокипящих органических растворителей. В большинстве таких процессов для делигнификации применяют химикаты, не содержащие серу. Наиболее часто используемые растворители для органосольвентной делигнификации включают в себя низшие спирты, такие как метанол и этанол (как правило, с долей воды 50 \%); органические кислоты, такие как муравьиная и уксусная кислота, и смешанные органические растворители [8]. Применение высококипящих растворителей для органосольвентной варки позволяет проводить процесс при атмосферном давлении. Одной из основных предпосылок для разработки процессов органосольвентной варки выступает их более высокая экологическая безопасность по сравнению с сульфатными и сульфитными технологиями [8].

Кроме того, некоторые органосольвентные процессы дают возможность отделить целлюлозу и гемицеллюлозы от лигнина, что оптимизирует переработку каждого из этих компонентов. Важно отметить, что из-за отсутствия в структуре серы органосольвентный лигнин является одним из наиболее подходящих видов технического лигнина для дальнейшей каталитической переработки.

Цель данного обзора заключается в анализе методов выделения и областей применения органосольвентных лигнинов.

\section{Методы выделения органосольвентных лигнинов и изучение их состава}

Органосольветные процессы делигнификации древесины обычно осуществляются в несколько этапов, включающих термическую обработку древесины органическими растворителями при небольшом давлении (1-6 атм.) в течение нескольких часов с последующим отделением маточного раствора и выделение лигнина из последнего.

Степень делигнификации древесины зависит от многих факторов: природы растворителя, наличия катализаторов, технологических параметров процесса. Все органосольветные процессы могут быть разделены на три типа: протекающие без катализаторов, в присутствии основных катализаторов и в присутствии кислотных катализаторов. При использовании основных (щелочных) катализаторов процесс фактически идет за счет гидролиза (омыления) $\beta$-эфирных связей в лигнине. Использование кислот в качестве катализатора приводит к расщеплению как $\beta$-эфирных, так $\alpha$-эфирных связей. Как правило, в процессе органосольвентной делигнификации извлекается около четверти лигнина, содержащегося в исходной биомассе.

$$
-457-
$$


Органосольвентные лигнины обычно получают при температуре не выше $250{ }^{\circ} \mathrm{C}$ при массовом соотношении древесины к раствору более 10. В качестве катализаторов в основном применяют минеральные кислоты (соляная и серная кислоты), соли металлов и аммония, реже гетероциклические и ароматические соединения.

В качестве растворителя обычно используют низкокипящие органические растворители (алифатические спирты, ацетон, этилацетат и др.), которые легко могут быть регенерированы перегонкой [9]. При использовании смеси растворителей катализатором может выступать один из компонентов - спирт (или кетон) и органическая кислота (уксусная, муравьиная и др.).

В процессе спиртовой варки древесины, в одном из наиболее развитых органосольвентных процессов, используют 50\%-ный раствор этанола. Процесс осуществляют в течение 90 мин при $190{ }^{\circ} \mathrm{C}$ и 28 атм. [10]. После окончания процесса целлюлозу отфильтровывают, из жидкой фракции отгоняют спирт и после центрифугирования в осадке остается этаноллигнин. Лигнин спиртовой делигнификации хорошо растворим в ацетоне, тетрагидрофуране и этилацетате и нерастворим в воде [11].

Многие автокаталитические и кислотно-каталитические органосольвентные процессы показали хорошие результаты для варки твердых пород древесины, но они часто не дают желаемых результатов для мягкой древесины. Для решения этой проблемы было предложено использовать щелочно-органосольвентные процессы. В работе [12] применяли гидроксид натрия для выделения метаноллигнина 50\%-ным раствором метанола при $170-190{ }^{\circ} \mathrm{C}$ в течение $60-90$ мин. Структура лигнина, полученного в таком процессе, является более измененной, чем лигнинов, полученных с использованием автокатализируемых или кислотно-катализируемых органосольвентных процессов, таких как спиртовая делигнификация.

Делигнификация древесины в органических растворителях облегчается в присутствии кислот. Было показано, что муравьиная и уксусная кислоты способствуют расщеплению $\alpha$-эфирных связей лигнина и растворения последующих фрагментов его деполимеризации [13]. Делигнификация при умеренной температуре и атмосферном давлении требует использования пероксида водорода или катализатора, такого как $\mathrm{HCl}$ [13], $\mathrm{H}_{2} \mathrm{SO}_{4}$ [14], $\mathrm{TiO}_{2}$ [15], $\mathrm{H}_{2} \mathrm{MoO}_{4}$ [16] и др. Было обнаружено [17], что делигнификация в присутствии муравьиной кислоты протекает быстрее, чем в случае применения уксусной кислоты. Эффективная делигнификация древесины с концентрированным раствором муравьиной кислоты достигнута при температуре 90-120 ㄷ и продолжительности процесса 30-90 мин [18].

Наряду с методами выделения органосольвентных лигнинов с помощью спиртов и органических кислот известны примеры использования других органических растворителей. В работах [19-21] описаны методы выделения ацетонлигнина с предварительным гидролизом биомассы. Было изучено влияние температуры в интервале $140-230^{\circ} \mathrm{C}$ и соотношении реагентов ацетон/вода от 50/50 до 90/10 и продолжительности процесса от 10 до 60 мин. Показано, что оптимальным условиям для получения ацетон-лигнина соответствуют следующие параметры: концентрация растворителя $75 \%$, температура $210{ }^{\circ} \mathrm{C}$ и продолжительность процесса 40 мин.

В работах $[19,22,23]$ показана возможность извлечения лигнина с помощью диоксана в различных концентрациях (от 25 до $100 \%$ при температурах в интервале $150-230{ }^{\circ} \mathrm{C}$ при продолжительности процесса 30-90 мин. Оптимальными условиями в данном случае является концентрация растворителя $75 \%$, температура $210{ }^{\circ} \mathrm{C}$ и продолжительность процесса 30 мин. 
Причем использование гидроксида натрия [22] или небольших количеств уксусной кислоты [23] ускоряет процесс выделения диоксан-лигнина.

Органосольвентные лигнины считаются более чистыми, чем технические с относительно небольшой молекулярной массой и достаточно узким молекулярно-массовым распределением. Они имеют низкую температуру стеклования, проявляют текучесть при нагревании и хорошо растворяются в органических растворителях. Далее рассмотрены некоторые результаты опубликованных в течение последних нескольких лет работ по изучению органосольвентных лигнинов физико-химическими методами.

В работе [24] для изучения органосольвентного лигнина, экстрагированного из травы Miscanthus giganteus водно-этанольными растворами, использовали методы ГПХ, ИКспектроскопии, ГХ-МС, 2D-ЯМР-спектроскопии и химического анализа. Показано, что в этаноллигнине преобладают связи $\beta$-О-4' (82-84 \%). Увеличение концентрации этанола в делигнифицирующем растворе приводит к снижению содержания углеводов в этаноллигнинах до 3,6-1,1 \%, повышает их растворимость в тетрагидрофуране, несколько снижает их молекулярную массу - до 2,72-2,25 кДа, увеличивает вклад реакций $\alpha$-этоксилирования с увеличением содержания этоксилированных фенилпропеновых соединений ( $n$-кумаровая и феруловая кислота).

В работе [25] для изучения физико-химических особенностей органосольвентных и щелочных лигнинов из листьев масличной пальмы использовали методы ИК-, ${ }^{1} \mathrm{H}$ и ${ }^{13} \mathrm{C}$ ЯМРспектроскопии. Обнаружено, что образцы лигнина содержат значительные количества неконденсированных гваяцильных и сирингильных единиц и несколько меньшее количество $n$-гидроксифенильных единиц, молярное отношение которых для органосольвентного лигнина составило 23:67:10.

Группа лигнинов, полученных из различных видов биомассы с использованием органосольвентного фракционирования, была исследована методом ИК-спектроскопии и термического анализа [26]. Установлены значительные различия между лигнинами лиственных пород, хвойных пород и злаковых из-за различий в сирингильных и гваяцильных единицах, а также условий процессов, используемых для выделения лигнинов.

В работе [27] травянистые лигнины, извлеченные из однолетних растений, были проанализированы с помощью ИК- и ${ }^{31}$ Р ЯМР-спектроскопии, ГПХ, ТГА, а также элементным и химическим анализом. Лигнины были экстрагированы органосольвентными методами из пшеницы, тритикале, кукурузы, льна и остатков конопли с использованием микроволнового излучения. Все полученные лигнины отличались низким содержанием сахаров, серы и золы. Установлено, что лигнины кукурузы, конопли и льна содержат высокие концентрации неметоксилированных фенольных групп, сирингильных фенольных групп и алифатических ОН-групп, что, соответственно, делает их перспективными кандидатами для производства фенольных смол, стабилизации полиолефинов и синтеза полиуретана. Лигнины тритикале и пшеницы отличались высоким содержанием ОН-групп, что делает их перспективными для синтеза полиэфиров.

Влияние условий экстракции на структуру получаемых этаноллигнинов, выделенных из древесины эвкалипта (Eucalyptus globules), изучено методами ИК-, УФ-, ${ }^{1} \mathrm{H}$ и ${ }^{31} \mathrm{P}$ ЯМРспектроскопии [28]. Установлено, что повышение жесткости условий органосольвентной обработки сопровождалось уменьшением содержания алифатических гидроксильных групп и 
увеличением содержания сирингильных фенольных единиц и конденсированных фенольных структур. Конденсированные фенольные структуры, количественно определенные в органосольвентном лигнине, соответствовали резинолу, фенилкумарану, дибензодиоксоцину, спиродиенону.

Этанол-лигнины, полученные из древесины четырех видов эвкалипта, были охарактеризованы методами ВЭЖХ, ИК, ТГА, химического анализа [29]. Все они имели высокую чистоту, низкий уровень сахаров и неорганических примесей и высокую полидисперсность. У лигнина из древесины эвкалипта метельчатого (Eucalyptus paniculata Sm) самую высокую среднюю молекулярную массу. Лигнин из эвкалипта лимонного (Corymbia citriodora Hook) имеет самую высокую среднюю величину соотношения сирингильных и гваяцильных единиц и самое низкое содержание суммарных фенолов.

Методами ИК-спектроскопии, ДСК и ТГА исследованы органосольвентные лигнины, выделенные из различных источников биомассы, таких как льняное волокно, люцерна, солома пшеницы, хвоя сосны [30]. Термические свойства экстрагированных лигнинов были изучены методами ТГА-ДСК. Установлено, что термические свойства образцов лигнина зависят от природы исходной биомассы. У лигнина, извлеченного из соломы пшеницы, самая большая термическая устойчивость и самый высокий выход несгораемого остатка $(40,41 \%)$ по сравнению с лигнинами из волокон льна $(39,22 \%)$, люцерны $(35,04 \%)$ и хвои сосны $(29,45 \%)$.

Лигнин, как и многие другие синтетические и природные полимеры, характеризуется средними статистическими величинами относительных молекулярных масс макромолекул, составляющих полимер. Для этого используется среднечисловая молекулярная масса $\left(M_{n}\right)$ и средневесовая молекулярная масса $\left(M_{w}\right)$ (уравнения (1) и (2)) [31, 32]. Индекс полидисперсности $(D)$ представляет собой молекулярно-массовое распределение полимеров (3) [33].

$$
\begin{aligned}
& M_{n}=\frac{\sum N_{i} M_{i}}{\sum N_{i}}, \\
& M_{w}=\frac{\sum N_{i} M_{i}^{2}}{\sum N_{i} M_{i}}, \\
& D=\frac{M_{w}}{M_{n}},
\end{aligned}
$$

где индекс $i$ представляет собой число различных молекулярных масс, присутствующих в образце лигнина, а $N_{i}$ является общим числом молей с молярной массой $M_{i}$.

Значения средних молекулярных масс и полидисперсности различаются в зависимости от вида биомассы, условий предварительной обработки и способа выделения лигнина [34]. Молекулярную массу лигнина можно определять с помощью осмометрии (парофазная осмометрия), ультрафильтрации, рассеяния света (статическое и динамическое (лазерная корреляционная спектроскопия)), масс-спектрометрии и гель-проникающей хроматографии (ГПХ). В табл. 1 приведены основные характеристики наиболее известных методов определения молекулярной массы лигнинов.

Парофазная осмометрия обычно используется для определения среднечисловых молекулярных масс в диапазоне от 100 до 10000 Да. Вне верхнего предела чувствительности метод

$$
-460-
$$


Таблица 1. Основные методы определения молекулярной массы лигнина

\begin{tabular}{|c|c|c|}
\hline $\begin{array}{c}\text { Метод } \\
\text { исследования }\end{array}$ & Принцип действия & $\begin{array}{c}\text { Дополнительная информация. } \\
\text { Диапазон измерений }\end{array}$ \\
\hline $\begin{array}{l}\text { Парофазная } \\
\text { осмометрия [35] }\end{array}$ & $\begin{array}{l}\text { Термисторы оценивают разницу температур } \\
\text { раствора полимера по сравнению с чистым } \\
\text { растворителем, которая пропорциональна } \\
\text { среднечисловой молекулярной массе } \\
\text { полимера } M_{n}\end{array}$ & $\begin{array}{l}\text { Подходит для низкомолекулярных } \\
\text { полимеров } \\
M_{n}=100-10000 \text { Да }\end{array}$ \\
\hline $\begin{array}{l}\text { Ультрафильтрация } \\
\text { [35] }\end{array}$ & $\begin{array}{l}\text { Мембрана разделяет лигнин по отсечкам, } \\
\text { которые ограничивают проход по размеру } \\
\text { молекул }\end{array}$ & $\begin{array}{l}\text { Не зависит от примесей } \\
M_{n}=1000-300000 \text { Да }\end{array}$ \\
\hline $\begin{array}{l}\text { Рассеяние света } \\
{[35,36]}\end{array}$ & $\begin{array}{l}\text { Лазерный луч проходит через образец и } \\
\text { рассеивает свет с интенсивностью, которая } \\
\text { пропорциональна его молекулярной массе }\end{array}$ & $\begin{array}{l}\text { Статическое рассеяние } \\
\text { света позволяет определить } \\
\text { абсолютную молекулярную массу } \\
\text { Мw, тогда как динамическое } \\
\text { рассеяние света требует } \\
\text { калибровки }\end{array}$ \\
\hline $\begin{array}{l}\text { Масс- } \\
\text { спектрометрия } \\
{[37,38]}\end{array}$ & $\begin{array}{l}\text { Электрон преобразует газообразную } \\
\text { нейтральную молекулу в катион-радикал, } \\
\text { который обладает удельной массой и зарядом }\end{array}$ & $\begin{array}{l}\text { Метод чувствителен к } \\
\text { высокополидисперсному лигнину }\end{array}$ \\
\hline $\begin{array}{l}\text { Гель-проникающая } \\
\text { хроматография } \\
{[39,40]}\end{array}$ & $\begin{array}{l}\text { Молекулы веществ разделяются по размеру } \\
\text { за счёт их разной способности проникать в } \\
\text { поры неподвижной фазы. При этом первыми } \\
\text { выходят из колонки наиболее крупные } \\
\text { молекулы, а последними - вещества с } \\
\text { малыми размерами молекул, свободно } \\
\text { проникающие в поры }\end{array}$ & $\begin{array}{l}\text { Широкий диапазон определяемых } \\
\text { молекулярных масс, } \\
\text { возможность модифицирования } \\
\text { и использования совместно с } \\
\text { другими методами }\end{array}$ \\
\hline
\end{tabular}

становится неудовлетворительным. Несмотря на это, парофазная осмометрия в настоящее время представляется предпочтительным методом определения среднечисловых молекулярных масс лигнинов и их производных. Все коллигативные методы сомнительны в диапазоне от 10000 до 25000 Да, и средние молекулярные массы в пределах этого диапазона трудно определить точно [41]. Принцип действия метода основан на измерении (при заданной температуре) давления паров растворителя для разбавленных растворов полимеров. Прибор должен быть откалиброван с веществом известной молекулярной массы.

Статическое рассеяние света (СРС) представляет собой метод для измерения абсолютной молекулярной массы, использующий зависимость между интенсивностью света, рассеянного молекулой, и её молекулярной массы и размером согласно теории Рэлея. Проще говоря, более крупные молекулы рассеивают больше света, чем более мелкие молекулы, из данного источника света и интенсивность рассеянного света пропорциональна молекулярной массе молекулы [35]. Существует два способа измерения абсолютной молекулярной массы методом статического рассеяния света: пакетное измерение с использованием кювет и в сочетании с хроматографией.

Пакетное измерение с использованием кювет применяют для определения средневесовой молекулярной массы всего измеренного образца. Этот метод, позволяющий измерить средневесовые молекулярные массы полимера, не может охватить весь диапазон молекулярных масс препаратов лигнина. Он пригоден лишь для определения молекулярных масс большее 10 000- 
20000 Да, хотя в некоторых случаях удается уменьшить нижний предел определяемых молекулярных масс до 5000 Да. Следует учитывать, что использование метода светорассеяния может привести к сильно завышенным результатам по молекулярной массе при наличии в растворе даже ничтожных количеств загрязнений типа коллоидных частиц. Тем не менее распространенным способом измерения абсолютной молекулярной массы является добавление детектора светорассеяния, например низкоуглового светорассеяния (LALS), правоуглового светорассеяния (RALS) или многоуглового светорассеяния(MALS) к системе ГПХ. Объединив метод рассеяния света с методикой разделения, можно вычислить абсолютную молекулярную массу в любой точке хроматограммы и становится возможным определение молекулярной массы любой части в смешанном образце [36, 42].

Мембранное разделение является относительно новой технологией, которая может быть использована для определения распределения молекул по размерам в образцах лигнина. Мембраны доступны для широкого диапазона молекулярных размеров (от 1000 до 300000 Да). Раствор лигнина фильтруют через последовательность мембран, и выходы фракций определяются путем взвешивания массовых долей лигнина или по поглощению в УФ-спектре. Основным преимуществом метода признана нечувствительность к загрязнениям. Лигнин проникает через ультрафильтрационные мембраны, почти не испытывая препятствий из-за наличия сахаров или неорганических солей. Такие примеси делают классические физические методы, такие как парофазная осмометрия и рассеяние света, непригодными для использования [35, 43].

Таким образом, у каждого из рассмотренных методов измерения молекулярной массы лигнина существуют свои особенности. Отличительной особенностью метода светорассеяния является его чувствительность к лигнинам с молекулярными массами больше 10000 Да, при этом точность метода возрастает с увеличением молекулярной массы. Метод парофазной осмометрии более чувствителен к соединениям, обладающим молекулярными массами $<25000$ Да. Авторы [41] исследовали применение методов парофазной осмометрии, ГПХ и низкоуглового лазерного рассеяния света (НУЛРС) для определения молекулярной массы, щелочных и органосольвентных лигнинов. Сделан вывод о целесообразности применения метода парофазной осмометрии для расчета $M_{n}$ и метода НУЛРС для расчета абсолютных значений $M_{w}$. Сочетание методов ГПХ и НУЛРС оптимально для определения как $M_{n}$, так и $M_{w}$. Методы ГПХ и матрично-активированной лазерной десорбции/ионизации время-пролетной массспектрометрии (МАЛДИ-ВП-МС) обычно дают близкие значения молекулярных масс. Метод МАЛДИ-ВП-МС наиболее подходит для определения молекулярной массы полимеров с низкой полидисперсностью $(D<1,2)$, в то время как метод ГПХ больше подходит для определения молекулярной массы полимеров с большими значениями полидисперсности. Использование метода ГПХ в комбинации с такими методами, как МАЛДИ-ВП-МС [44] и низкоугловое светорассеяние [45] или многоугловое лазерное рассеяние света [46], обеспечивает получение более точных значений молекулярной массы.

В настоящее время метод ГПХ, также известный как эксклюзионная хроматография, наиболее популярен для определения молекулярной массы лигнинов [35, 39, 40]. Привлекательность метода ГПХ обусловлена коротким временем определения (от 30 мин до 5 ч на образец), миллиграммовыми количествами образца, его толерантностью к синтетическим и природным полимерам, а также широким диапазоном обнаружения молекулярной массы. 
Данный метод измерения размеров макромолекул основан на молекулярном просеивании в хроматографической колонке. Процедура включает в себя пропускание раствора макромолекул через колонку, заполненную пористым гелем. В зависимости от размера макромолекулы могут диффундировать в различных пропорциях в пористый гель. Молекулы с малым гидродинамическим радиусом могут проникать в гель, в то время как большие молекулы вымываются из геля. Объем элюирования любой конкретной фракции является функцией размеров макромолекул и размеров пор в геле.

Для того чтобы преобразовать объемы элюирования в молекулярную массу, должны быть известны соотношения между размером молекул и молекулярной массой растворенного вещества [35]. Самый простой способ - это использование монодисперсных фракций полимеров с известной молекулярной массой для установления связи между молекулярной массой и объемом элюирования. Было установлено, что элюирование с тетрагидрофураном для лигнина молотой древесины (лигнина Бьёркмана) дает надежные результаты определения молекулярной массы [47]. Это позволило успешно определить значения $M_{n}$ и $M_{w}$ лигнинов молотой древесины, кислотно-гидролизованных, паровзрывных, крафт и органосольвентных лигнинов. При этом установлено, что ГПХ является подходящим методом для изучения различных видов лигнина.

Перед проведением анализа методом ГПХ часто осуществляется дериватизация лигнина с помощью метилирования, ацетилирования или силицирования для повышения растворимости лигнина в органическом растворителе [35]. Однако высокая продолжительность полного растворения в органических растворителях модифицированных таким образом лигнинов ограничивает применение этих подходов. Исследования показали, что ацетилирование пригодно для растворения (> 90 \%) и полного растворения лигнина из различных источников биомассы в тетрагидрофуране (ТГФ). Тем не менее в работе [48] обнаружено, что только 54 \% ацетилированного лигнина норвежской ели растворяется в ТГФ после 20 ч обработки и этот показатель возрастает до $60 \%$ через 6 дней [48].

Использование ацетобромирования и ионных жидких сред - альтернативный подход к получению растворимых лигнинов. Ацетобромирование норвежской ели в ледяной уксусной кислоте приводит к полному растворению лигнина в течение 0,5 ч. Непрореагировавший лигнин растворяется в таких растворителях, как диметилформамид (ДМФ) и диметилсульфоксид (ДМСО), но при этом остается чувствительным к эффектам ассоциации, которые потенциально приводят к снижению воспроизводимости и надежности данных определения молекулярной массы [49-51]. Механизмы эффектов ассоциации интенсивно изучались с помощью гельпроникающей хроматографии $[40,51]$. Для минимизации эффектов ассоциации в ДМФ или ДМСО часто добавляют бромид лития или хлорид лития [50]. Например, авторы [52] использовали высокоэффективную ионно-парную эксклюзионную хроматографию с гелевыми колонками из стирол-дивинилбензола и четвертичного амина, чтобы установить молекулярную массу органосольвентных и крафт-лигнинов в тетрагидрофуране без получения их производных. Четвертичные амины образуют комплексы с лигнином, которые успешно минимизируют адсорбцию колонки и уменьшают эффекты ассоциации.

Для построения калибровочной кривой для измерений методами ГПХ часто используются полистирольные стандарты, которые требуют органических растворителей. Молекуляр-

$$
-463-
$$


ные массы этих стандартов находятся в диапазоне до 10000 кДа с полидисперсностями ниже 1,1. Гидродинамические объемы лигнина и полистирола отличаются, что свидетельствует о том, что ГПХ не является абсолютным методом определения молекулярной массы [39]. Тем не менее оценка молекулярной массы лигнина с использованием ГПХ надежна для водных или органических растворителей в присутствии стандартов полистирола или стандартов на основе лигнина для построения калибровочной кривой [53].

В методе парофазной осмометрии также возможно использование ацетосольвентных лигнинов с полидисперсностями около единицы в качестве стандартов для калибровки. Калибровочные кривые полистирола и ацетосольвентных лигнинов накладываются друг на друга почти идеально. Исследования подтвердили, что монодисперсные щелочные лигнины могут быть использованы в качестве стандартов для построения калибровочной кривой для измерений методом ГПХ. Значения $M_{n}$ лигносульфонатов, рассчитанные по стандартной кривой, равны 17600 Да, что на 700 Да меньше, чем значение, рассчитанное с помощью ультрацентрифугирования $[54,55]$.

В табл. 2 приведены молекулярно-массовые распределения лигнинов из различных видов растительного сырья. Из полученных данных следует, что параметры молекулярно-массового распределения лигнинов зависят от природы исходной лигноцеллюлозной биомассы и способов выделения лигнинов из биомассы.

Таким образом, несмотря на наличие широкого спектра методик и приборов для определения молекулярных масс, у всех имеются свои достоинства и недостатки. Так, парофазная осмометрия подходит только для низкомолекулярных полимеров, ультрафильтрация требует качественных калибровочных стандартов, метод светорассеяния очень чувствителен к загрязнениям, а перспективный метод матрично-активированной лазерной десорбции/ионизации с время-пролетной масс-спектрометрией рассчитан на полимеры с низкой полидисперсностью. Свои недостатки есть и у классического метода гель-проникающей хроматографии, в частности сложность подбора калибровочных стандартов.

Стоит отметить, что лигнины представляют собой класс полимеров с очень разнообразной структурой и свойствами, поэтому ни один из вышеуказанных методов не будет давать точные характеристики молекулярных масс и полидисперсности. Однако комбинация методов гель-проникающей хроматографии с другими позволит преодолеть эти ограничения. Так, при использовании детектора светорассеяния с ГПХ отпадает необходимость в сложных калибровочных стандартах на основе лигнина и возможно использовать монодисперсные полистирольные стандарты без ущерба для точности определений.

Широкий выбор хроматографических колонок для ГПХ позволяет анализировать лигнины и их производные, растворяющиеся в различных растворителях. Например, тетрагидрофуран с колонкой на органические растворители применяется для определения молекулярных масс дериватизованных лигнинов, полученных методами ацетилирования, ацетобромирования и др. Система колонок с использованием полярных растворителей (диметилсульфоксид, диметилформамид, диметилацетамид) позволяет определять широкий класс нативных лигнинов, полученных различными методами без дериватизации. Однако данный метод требует добавления солей лития для устранения эффектов ассоциации. Системы с водными растворами и соответствующими колонками применяются для анализа сильно гидрофильных лигнинов.

$$
\text { - } 464-
$$


Таблица 2. Молекулярно-массовое распределение лигнина из измельченной древесины и выделенного из предварительно обработанной биомассы

\begin{tabular}{|c|c|c|c|c|c|}
\hline Биомасса & Тип обработки & $\mathrm{M}_{\mathrm{n}}($ Да) & $\mathrm{M}_{\mathrm{w}}($ Да) & $\mathrm{D}$ & Литература \\
\hline \multirow[t]{2}{*}{ Стебель хлопка } & ЛМД & 700 & 1520 & 2,17 & \multirow[t]{2}{*}{ [56] } \\
\hline & $\begin{array}{l}\text { Аммонийный } \\
\text { гидротермальный }\end{array}$ & $560-890$ & $1250-1740$ & $1,83-2,23$ & \\
\hline \multirow[t]{2}{*}{ Бамбук \{Bambusa rigida $\mathrm{sp}\}$} & ЛМД & 1680 & 3260 & 1,93 & \multirow[t]{2}{*}[57]{} \\
\hline & ЩЛ & 1860 & 2840 & 1,5 & \\
\hline \multirow[t]{3}{*}{ Береза \{Betula alnoides\} } & ЛМД & 5860 & 10,860 & 1,85 & \multirow[t]{3}{*}[58]{} \\
\hline & Микроволны & 3830 & 7290 & 1,90 & \\
\hline & Нагрев & 5000 & 11,450 & 2,29 & \\
\hline \multirow[t]{2}{*}{ Бук $\{$ Fagus sylvatica $\}$} & ЛМД & 3690 & 5510 & 1,49 & \multirow[t]{2}{*}{ [59] } \\
\hline & Нагрев & 2790 & 4020 & 1,44 & \\
\hline \multirow{5}{*}{$\begin{array}{l}\text { Сосна Лоблолли } \\
\{\text { Pinustaeda }\}^{\circ}\end{array}$} & ЛМД & 989 & 7790 & 7,9 & \multirow[t]{5}{*}[60,61]{} \\
\hline & Ceriporiopsis subvermispora & $743-770$ & $5147-6330$ & $6,7-8,5$ & \\
\hline & ЛМД & 7590 & 13,500 & 1,77 & \\
\hline & ОС-ЛМД & 6530 & 16,800 & 2,57 & \\
\hline & ЭОЛ & 3070 & 5410 & 1,77 & \\
\hline \multirow{2}{*}{$\begin{array}{l}\text { Тополь }\{\text { Populus } \\
\text { trichocarpa }\}\end{array}$} & ЛМД & - & 8550 & 2,7 & \multirow[t]{2}{*}{ [62] } \\
\hline & КЛ & - & $7500-8280$ & $2,2-3,0$ & \\
\hline \multirow{3}{*}{$\begin{array}{l}\text { Проco \{Panicum virgatum } \\
\text { var. Kanlow\} }\end{array}$} & ЛМД & 2070 & 5100 & 2,5 & \multirow[t]{3}{*}{ [63] } \\
\hline & ЭОЛ & 980 & 4200 & 4,3 & \\
\hline & \begin{tabular}{|l} 
Органосольвентный \\
этанолом + измельчение
\end{tabular} & 1580 & 5750 & 3,6 & \\
\hline \multirow{3}{*}{$\begin{array}{l}\text { Осина \{Populus } \\
\text { albaglandulosa\} }\end{array}$} & ЛМД & 4176 & 13,250 & 3,17 & \multirow[t]{3}{*}{ [64] } \\
\hline & Сверхкритическая вода & $1042-1357$ & $1655-4429$ & $1,59-3,26$ & \\
\hline & $\begin{array}{l}\text { Сверхкритическая вода }+ \\
\text { катализатор }\end{array}$ & $949-1097$ & $1526-2753$ & $1,55-2,63$ & \\
\hline \multirow{2}{*}{$\begin{array}{l}\text { Гребенщик ветвистый } \\
\text { \{Tamarix ramosissim\} }\end{array}$} & ЛМД & 2155 & 3750 & 1,74 & \multirow[t]{2}{*}[65]{} \\
\hline & Сверхкритическая вода & $1380-2250$ & $2690-3950$ & $1,76-1,95$ & \\
\hline $\begin{array}{l}\text { Опилки сосны скрученной } \\
\text { широкохвойной }\end{array}$ & Сульфитная (LS-SP165) & 810 & 1440 & 1,77 & {$[66]$} \\
\hline $\begin{array}{l}\text { Коммерческая хвойная } \\
\text { древесина }\end{array}$ & Сульфитная (LSD-748) & 4800 & 14,000 & 2,92 & {$[66]$} \\
\hline \multirow[t]{4}{*}{ Солома пшеницы } & Уксусная кислота & $2330-2760$ & $3960-4330$ & $1,57-1,70$ & \multirow[t]{4}{*}[67]{} \\
\hline & $\begin{array}{l}\text { Уксусная+муравьиная } \\
\text { кислоты }\end{array}$ & $2650-2660$ & $4140-4170$ & $1,56-1,57$ & \\
\hline & Метанол & 2630 & 4340 & 1,65 & \\
\hline & этанол & 2500 & 4280 & 1,71 & \\
\hline \multirow[t]{2}{*}{ Ель $\{$ Douglas fir $\}$} & ЛМД & & 7760 & & \multirow[t]{2}{*}{ [68] } \\
\hline & $\begin{array}{l}\text { Глубокие эвтектические } \\
\text { растворители }\end{array}$ & & 1340 & & \\
\hline \multirow[t]{2}{*}{ Бамбук $\{$ Bamboo $\}$} & ЛМД & 5410 & 12090 & 2,23 & \multirow[t]{2}{*}{ [69] } \\
\hline & КЛ (муравьиная) & 4450 & 10020 & 2,23 & \\
\hline
\end{tabular}

ЛМД - лигнин молотой древесины (лигнин Бьёркмана); ЩЛ - щелочной лигнин; КЛ - предварительная обработка разбавленными кислотами; ЭОЛ - этанольный органосольвентный лигнин; ОС-ЛМД - органосольвентный лигнин из измельченной древесины. 

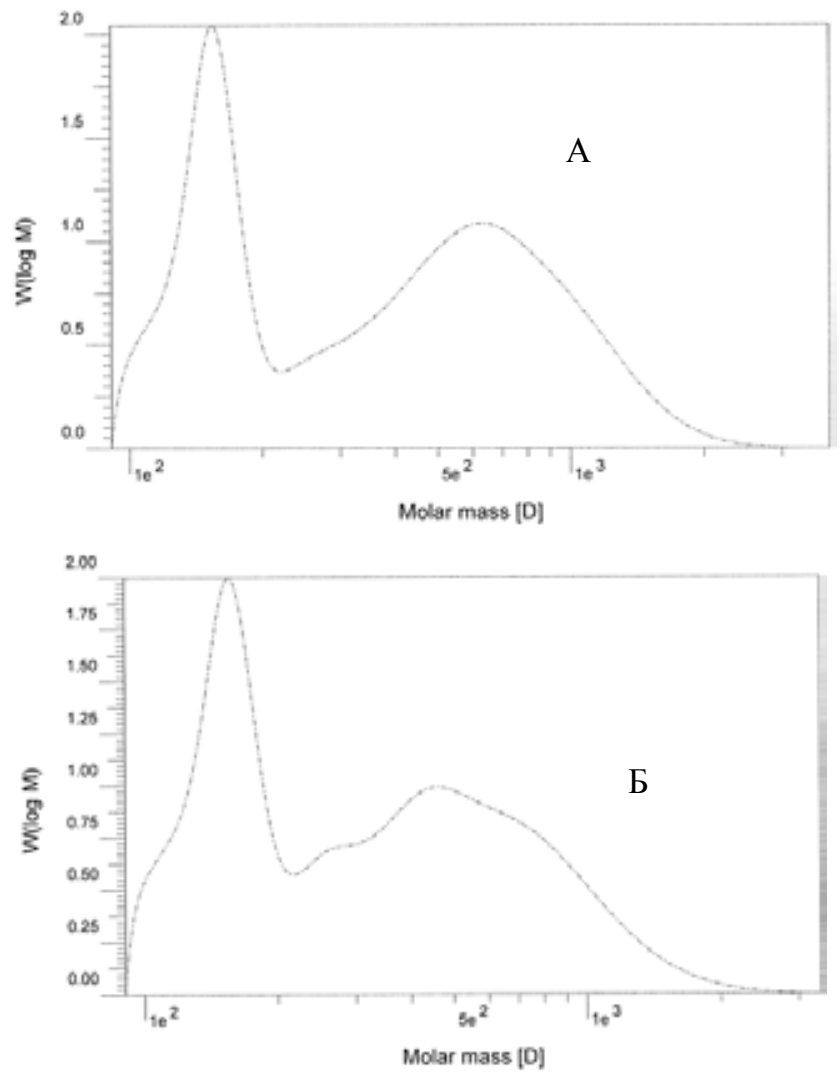

Рис. 1. Гель-проникающие хроматограммы образцов этаноллигнина из пихты (А) и осины (Б)

Молекулярная масса и молекулярно-массовое распределение образцов этаноллигнина, выделенных из древесины осины и пихты, исследованы с помощью метода гель-проникающей хроматографии. Молекулярно-массовое распределение обоих образцов этаноллигнина характеризуется наличием двух пиков: широкого (индекс полидисперсности $1,28-1,30$ ) и более узкого (индекс полидисперсности 1,04) с диапазоном масс 200-1200 Да (рис. 1).

Соотношение площадей этих пиков составляет примерно 60:40. Для образца этаноллигнина пихты наблюдается смещение широкого пика в низкомолекулярную область по сравнению с этаноллигнином осины. Максимум пика соответствует 476 Да для этаноллигнина пихты и 660 Да для этаноллигнина осины. Средневесовая молекулярная масса этаноллигнина пихты равна 478 Да, а этаноллигнина осины - 750 Да. Таким образом, изученные образцы этаноллигнина имеют довольно низкую молекулярную массу, что должно облегчить их дальнейшую переработку в жидкие углеводороды и аэрогели.

\section{Применение органосольвентных лигнинов}

Органосольвентные лигнины не содержат серы и обладают гидрофобными свойствами. Они практически нерастворимы в воде, но растворяются во многих органических растворителях. Поскольку органосольвентные лигнины имеют более низкую молекулярную массу, чем традиционные технические лигнины, они проявляют более высокую реакционную способ-

$$
-466-
$$


ность в процессах каталитической деполимеризации в жидкие фенольные и ароматические продукты.

Лигнины, выделенные в процессе уксуснокислотной варки древесины различных пород и соломы пшеницы, имеют высокую концентрацию реакционных кислородсодержащих групп, что позволяет использовать их в качестве низкотоксичных связующих веществ для производства древесных плитных материалов с хорошими прочностными характеристиками [70]. Изучено влияние природы лигнина, его содержания в смеси лигнин/древесина и условий прессования на прочность и водостойкость получаемых древесных панелей. Установлены оптимальные технологические параметры для производства прочных и устойчивых к действию влаги древесных плитных материалов.

Органосольвентные лигнины также могут использоваться для получения энтеросорбентов и нанопористых углеродных материалов $[71,72]$. Перспективно их применение для получения органических и углеродных аэрогелей [73].

Из анализа литературных источников можно выделить следующие основные процессы конверсии лигнинов в жидкие фенольные и ароматические углеводороды: пиролиз, каталитическое гидрирование, щелочная деполимеризация, деполимеризация в сверхкритических флюидах.

Пиролиз лигнина происходит в более широком диапазоне температур (160-900 $\left.{ }^{\circ} \mathrm{C}\right)$ по сравнению с полисахаридами (220-400 $\left.{ }^{\circ} \mathrm{C}\right)$ [74]. Кроме того, количество твердого остатка, образующегося при пиролизе лигнинов, значительно выше, чем при пиролизе полисахаридов или лигноцеллюлозной биомассы. Биомасла, полученные пиролизом органосольвентных лигнинов, представляют собой сложные смеси ароматических и неароматических углеводородов с широким молекулярно-массовым распределением. Пиролиз различных типов органосольвентных лигнинов подробно описан в работах [75-82]. Использование твердых кислотных катализаторов, таких как HZSM-5, в пиролизе лигнина может приводить к изменению фракционного состава жидких продуктов и снижать содержание в них кислорода.

При каталитической гидрогенизации лигнинов протекают различные химические реакции, в том числе расщепление $\mathrm{C}-\mathrm{O}-$ и $\mathrm{C}-\mathrm{C}$-связей, деоксигенирование, гидрогенизация ароматического кольца, удаление алкильных и метоксильных заместителей, что приводит к образованию сложной смеси углеводородов. Однако более низкое содержание кислорода в жидких продуктах процесса гидропиролиза делает их более пригодными для химической переработки в моторные биотоплива по сравнению с биожидкостями высокоскоростного пиролиза.

Деполимеризация лигнина в суб- и сверхкритической воде вызывает получение низкомолекулярных фрагментов путем разрыва эфирных связей. При этом возможно образование и более крупных молекул сшиванием реакционноспособных фрагментов, преимущественно по механизму Фриделя-Крафтса [83-86]. При теромообработке лигнина в гидротермальной среде также происходит деалкилирование и деметоксилирование.

В работах [87-90] было показано, что добавление солей щелочных металлов к докритической воде оказывает положительное влияние на выход биомасла. При увеличении времени реакции выход биомасла достигает максимума, после чего он уменьшается из-за реакций конденсации. Независимо от концентрации щелочи и лигнина максимальный выход продуктов с низким молекулярным весом едва превышает одну треть от исходного лигнина. Добавление

$$
-467-
$$


фенольных соединений (фенол, $n$-крезол) $[84,91,92]$ или других органических веществ, таких как бутанол [93] и борная кислота [88], к реакционной смеси увеличивает конверсию лигнина в сверхкритической воде и выход жидких продуктов. Такое улучшение конверсии и селективности достигается в результате ингибирования фенольными соединениями реакций конденсации фрагментов деполимеризации лигнина.

Для деполимеризации органосольвентных лигнинов используются такие сверхкритические растворители, как этанол [94-98], метанол [99-101], $\mathrm{CO}_{2} /$ ацетон/вода [102], бутанол [93, 103]. Деполимеризацию лигнина в сверхкритических органических растворителях, как правило, проводят в интервале температур $200-350{ }^{\circ} \mathrm{C}$ и при повышенных давлениях. Также для деполимеризации лигнинов в сверхкритических органических растворителях могут быть дополнительно использованы газообразный водород или водородно-донорные растворители, такие как муравьиная кислота [104, 105],

Использование катализаторов позволяет интенсифицировать деструкцию лигнина и увеличить выход жидких продуктов [106-111].

В различных процессах термического превращения лигнина проявляют активность катализаторы на основе диоксида циркония [112-115]. В частности, использование катализатора $\mathrm{ZrO}_{2}$ в процессе термоконверсии лигнина в среде сверхкритической воды позволяет резко увеличить выход метана и водорода [112]. Катализатор $\mathrm{ZrO}_{2}-\mathrm{Al}_{2} \mathrm{O}_{3}-\mathrm{FeO}_{\mathrm{x}}$ ускоряет реакции разложения мономеров и димеров лигнина в среде водяного пара [113].

Показано, что кислотные цеолитные катализаторы, такие как HZSM-5, не только увеличивают конверсию лигнина в жидкие продукты в процессе его пиролиза [111], но и способствуют образованию ароматических углеводородов путем деоксигенации метоксифенольных соединений [107]. Исследовано влияние силикатного модуля (Si/Al), кислотности, пористости цеолитов и их количества на выход и состав продуктов каталитического пиролиза лигнина [108]. Установлено, что низкий силикатный модуль и высокое содержание кислотных центров приводят к ускорению реакций образования ароматических углеводородов. Большой размер пор препятствует закоксовыванию катализаторов.

Эффективная деполимеризация лигнина может быть осуществлена путем его термической конверсии в низших алифатических спиртах, находящихся в сверхкритическом состоянии. Известно, что использование флюидов в процессах «зеленой» химии позволяет увеличить выход экстрагируемых продуктов [116]. Выбор спиртов обусловлен тем, что значения их критических температур ниже либо близки к области оптимальных температур термической деструкции лигнина. Кроме того, биоспирты получают в процессе гидролиза, отходом которого является лигнин. Это обстоятельство позволяет организовать переработку лигнина на месте его образования без использования дополнительных реагентов.

В процессе термического растворения спирты не только экстрагируют продукты термической фрагментации лигнина, но и способны их алкилировать, предотвращая вторичные реакции образования высокомолекулярных веществ [117,118]. Показано, что в сверхкритических условиях метанол и этанол способствуют деполимеризации лигнина за счет разрыва фенилэфирных связей [119].

Установлено, что в процессе термической конверсии лигнина древесины осины в среде сверхкритического этанола в присутствии твердых кислотных катализаторов наиболее высо- 
кие значения выхода фракции жидких продуктов, выкипающих ниже $180{ }^{\circ} \mathrm{C}$, достигаются для катализаторов на основе сульфатированного $\mathrm{ZrO}_{2}$ при температуре $400{ }^{\circ} \mathrm{C}$, а фракции жидких продуктов, кипящих выше $180{ }^{\circ} \mathrm{C}$, - для цеолитных катализаторов при $350{ }^{\circ} \mathrm{C}$ [120]. Сульфатированные $\mathrm{ZrO}_{2}$-содержащие катализаторы увеличивают в 1,4-1,5 раза степень превращения лигнина в жидкие и газообразные продукты. При этом резко возрастает выход фракции жидких продуктов, выкипающей выше $180^{\circ} \mathrm{C}$, увеличивается содержание в жидких продуктах 1,1 диэтоксиэтана при существенном снижении содержания фенола и его производных.

Максимальные значения конверсии лигнина (71 мас. \%) и выхода легкокипящей $\left(<180{ }^{\circ} \mathrm{C}\right)$ фракции жидких продуктов (44 мас. \%) получены при температуре $350{ }^{\circ} \mathrm{C}$ в присутствии цеолитного катализатора с силикатным модулем 30. Применение в процессе термоконверсии лигнина цеолитных катализаторов является предпочтительным, поскольку на $\mathrm{ZrO}_{2}$-содержащих катализаторах с высоким выходом образуются газообразные продукты.

Жидкие продукты термоконверсии лигнина в этаноле в присутствии цеолитных катализаторов, как и в случае систем на основе $\mathrm{ZrO}_{2}$, состоят из большого количества органических соединений. Они образуются в результате конверсии этанола (простые и сложные эфиры) и лигнина (производные бензола и фенола). Использование сульфатированных катализаторов $\mathrm{ZrO}_{2}$ и $\mathrm{ZrO}_{2}-\mathrm{Al}_{2} \mathrm{O}_{3}$ снижает содержание фенолов в жидких продуктах соответственно в 4,6 и 3 раза при одновременном увеличении выхода алифатических спиртов (преимущественно бутанолов) и 1,1-диэтоксиэтана.

Фенольная часть жидких продуктов конверсии лигнина на цеолитных катализаторах при $350{ }^{\circ} \mathrm{C}$ представлена в основном метоксифенолами сирингильного и гваяцильного типов и их метил- и этилпроизводными. Повышение температуры процесса термоконверсии лигнина на цеолитных катализаторах до $400{ }^{\circ} \mathrm{C}$ приводит к значительному (от 4 до 16 раз) снижению содержания фенолов в жидких продуктах по сравнению с некаталитическим процессом.

Органосольвентные лигнины имеют перспективы использования при получении аэрогелей - нового класса пористых материалов - с широким потенциалом применения в различных областях [121-124]. Материалы аэрогельного типа, как правило, получают зольгель-полимеризацией смолы с последующим обменом растворителя в порах геля и сушкой, чтобы получить окончательный пористый продукт. Фенольные смолы, такие как резорцинформальдегидные, являются хорошо известными и широко изученными с целью получения аэрогелей [125]. Производственные затраты при получении органических аэрогелей довольно высоки, поэтому поиск нового пути производства и новых сырьевых источников для получения коммерчески привлекательных аэрогелей остается актуальным.

Природные полимеры из возобновляемых ресурсов, содержащие фенольные мономеры, могут быть использованы в качестве замены резорцина и фенола. Лигнин считается потенциальным источником фенолов для такого рода смол, который может быть применен в качестве замены токсичного и дорогого сырья, обычно используемого для изготовления органических и углеродных аэрогелей.

В работах $[126,127]$ замещали часть резорцина лигнином при получении резорцинлигнин-формальдегидных аэрогелей с использование $\mathrm{NaOH}$ в качестве катализатора. Исследовано влияние нескольких параметров, таких как содержание лигнина, концентрация лигнин-резорцин-формальдегидной смолы, весовое отношение лигнин-резорцина к катализа- 
тору, молярное соотношение лигнин-резорцина к формальдегиду, температура гелирования на плотность и пористую структуру полученных аэрогелей. Повышение концентрации лигнина от 5 до 30 мас. \% приводило к увеличению плотности аэрогелей, которая колебалась в пределах от 0,24 до 0,49 г/см³. Увеличение количества лигнина вызывало также уменьшение площади поверхности БЭТ (от 480 до $191 \mathrm{~m}^{2} / \Gamma$ ) и объема микро- и мезопор, но при этом диапазон распределения пор по размерам становился шире. Средняя ширина пор в образцах варьировалась в диапазоне от 5,89 до 13,67 нм.

Для улучшения конечных свойств аэрогеля (например механических, тепловых и электрических и т.д.) было предложено множество методик. Так, производство гибридных аэрогелей, которые включают в себя как неорганическую, так и органическую фазу, встраивание наночастиц в матрицу геля, формирование взаимопроникающих сетей и армирование волокнами и наполнителями являются примерами изученных подходов [128-130].

Для получения гибридного альгинат-лигнинового аэрогеля предложено использовать сжатый углекислый газ для усиления гелеобразования [128]. При весовом соотношении альгината натрия к лигнину (2:1) были сформированы стабильные гидрогели. Данный подход позволил получить аэрогели с низкими показателями плотности в диапазоне $0,03-0,07$ г/см ${ }^{3}$ и высокими значениями удельной поверхности и удельного объема пор, значения которых превышают $564 \mathrm{~m}^{2} / \Gamma$ и 7,2 $\mathrm{cm}^{3} / \Gamma$ соответственно. В данной работе не наблюдалось четкой зависимости текстурных и морфологических свойств аэрогелей от содержания лигнина. Сшивание лигнина с альгиновой кислотой или ее солями (альгинатами) приводит к формированию легких, но более механически прочных аэрогелей.

В работе [131] сообщается о получении лигнин-резорцин-формальдегидных аэрогелей, модифицированных нановолокнами бактериальной целлюлозы. Бактериальная целлюлоза была использована в качестве армирующего материала с целью повышения эластичности и упругости углеродных аэрогелей. Бактериальную целлюлозу пропитывали лигнин-резорцинформальдегидным раствором (ЛРФ), дальнейшая поликонденсация ЛРФ происходила на волокнах целлюлозы, и последующая их сушка и карбонизация приводила к конечному продукту. Углеродные аэрогели, полученные по данной методике, имеют упорядоченную структуру и большое количество мезопор (до 95 \% от общего объема пор).

При получении пористого материала аэрогельного типа важным этапом является не только выбор сырьевых ресурсов, но и процесс сушки аэрогеля для удаления молекул жидкости, находящихся в его порах. В настоящее время существует три основных режима сушки (рис. 2). Традиционный, т.е. докритическая сушка при атмосферных условиях, приводит к образованию ксерогелей. Такая сушка может быть осуществлена с помощью различных способов: испарения, конвективной сушки и даже сушки микроволнами. Сверхкритическая сушка вызывает образование аэрогелей, тогда как лиофилизация - получение криогелей.

Поскольку аэрогель имеет много микроскопических пор, нахождение в них жидкости создает там высокие давления. Поэтому высушивание аэрогелей на воздухе или в вакууме создает большие внутренние напряжения в его каркасе, что приводит к его сжатию, а в некоторых случаях и к разрушению. Высушенный таким способом аэрогель, который носит название ксерогеля, сохраняет пористую структуру, однако его удельный вес существенно выше, а удельный объем внутренних пор значительно ниже, чем у аэрогеля. С экономической точки зрения суш- 


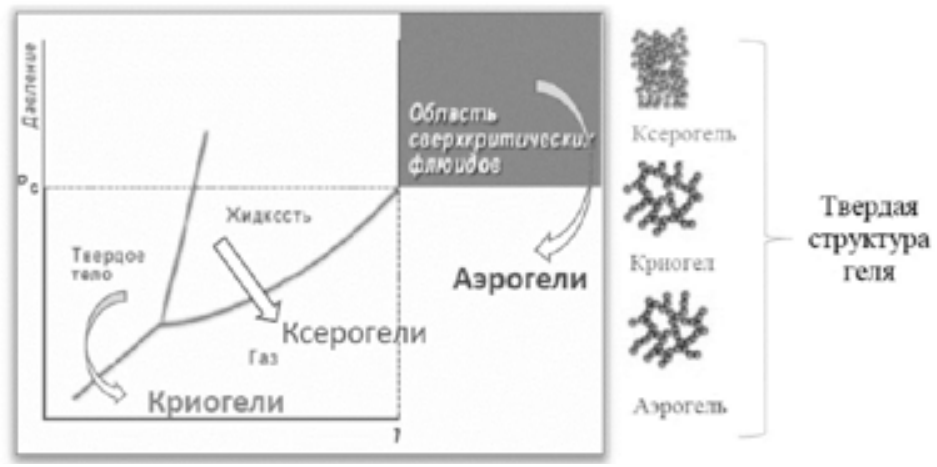

Рис. 2. Диаграмма состояния растворителя внутри геля при различных режимах его сушки и структура полученного пористого материала

ка при атмосферном давлении наиболее привлекательна. И в последние годы усилия многих исследовательских групп направлены на получения ксерогелей.

В работе [133] показано, что на основе лигнина могут быть получены ксерогели, имеющие гидрофобную самоочищающуюся поверхность. Приготовление таких ксерогелей осуществляли путем золь-гелевой полимеризации лигнина с модифицированным диизоцианатом в растворе тетрагидрофурана, и после образования геля его сушку осуществляли на воздухе при атмосферном давлении. Полученные ксерогели демонстрировали селективное поглощение масла в смеси вода-масло, что позволяет использовать такой материал в качестве нефтесобирателя.

Для введения новых функциональных групп в традиционные лигнин-резорцинформальдегидные органические ксерогели, которые могли бы улучшить их адсорбционную способность, для их приготовления использовали лигнин, полученный из выжатого сахарного тростника [134]. Исследовано влияние соотношения исходных компонентов на физические и текстурные характеристики полученных гелей (степень усадки, плотность, пористость), высушенных на воздухе. Насыпная плотность полученных материалов изменялась в пределах

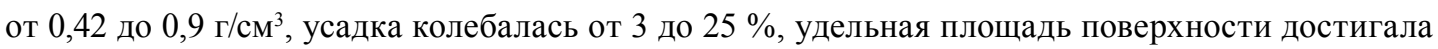
$452 \mathrm{M}^{2} / \Gamma$ при содержании лигнина 13 мас. \% и 270 м²/г при содержании лигнина 27 мас. \%.

Осуществлен синтез аэрогелей из лигнина пшеничной соломы с использованием мономерных и олигомерных эпоксидных смол в качестве сшивающих агентов [135]. Реакция сшивания протекает в относительно мягких условиях (при комнатной температуре) и при меньшей продолжительности гелеобразования (24 ч) по сравнению с реакциями лигнин-фенол и лигнинрезорцина с формальдегидом $\left(85^{\circ} \mathrm{C}, 5\right.$ дней). Установлено, что гидрофильность, тип сшивающего агента и его концентрация имеют существенное влияние на время гелеобразования, а также и на насыпную плотность, степень усадки, площадь поверхности и средний размер пор аэрогеля. Этот новый тип органических аэрогелей на основе лигнина отличается относительно

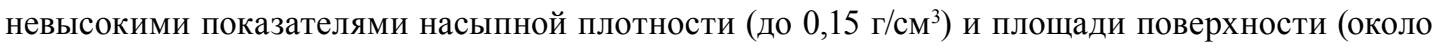
$120 \mathrm{M}^{2} /$ г) и пористостью в пределах от 75 до $88 \%$.

Для получения пористых материалов на основе лигнина в работах $[136,137]$ был использован непосредственно сульфатный щёлок. Авторы сначала вводили в черный щелок, содержащий приблизительно 40 мас. \% лигнина, эпихлоргидрин в качестве сшивающего агента и 
поверхностно-активного вещества. Затем добавляли касторовое масло (55 обм. \%) для получения щелок-касторовой эмульсии, которую нагревали для сшивания лигнина с эпихлоргидрином. Полученные монолитные материалы затем экстрагировали этанолом для удаления масла и получения конечного пористого продукта. В зависимости от природы и количества поверхностно-активного вещества получали пустоты различного размера диаметром от 5 до 20 мкм.

В наших предыдущих работах $[73,138]$ впервые были синтезированы аэрогели с содержанием лигнина до 90 мас. \%. В работе [73] кроме лигнина как природного источника фенолов использовался также и танин. В другой работе [138] в сочетании с лигнином был использован фенол. Фенол является менее реакционноспособным по отношению к формальдегиду, чем резорцин, но он менее дорогая альтернатива для производства аэрогеля. Было исследовано влияние содержания лигнина и метода сушки (экстракция $\mathrm{CO}_{2}$, находящимся в сверхкритическом состоянии, против сублимационной сушки) на физические и структурные свойства аэрогеля (табл. 3). Установлено, что увеличение содержания лигнина в реакционной смеси приводило к снижению плотности и увеличению пористости аэрогелей.

Как правило, образцы аэрогелей, которые высушивали при сверхкритических условиях, имели более низкую плотность и более высокую пористость, чем криогели, высушенные с помощью лиофильной сушки.

Проведенное изучение пористой структуры органических ЛФФ-гелей методом равновесной адсорбции-десорбции азота при $77 \mathrm{~K}$ в диапазоне относительных давлений $\mathrm{P} / \mathrm{P}_{0}$ от 0,005 до 0,999 на анализаторе ASAP 2020 (Micromeritics, США) показало, что полученные объекты относятся к микро/мезопористым материалам. Значения удельного объема пор изученных органических гелей колеблется в пределах 0,4-3,6 см³/г (табл. 3). При этом значение удельной площади поверхности изменяется в интервале от 120 до $490 \mathrm{~m}^{2} / \Gamma$ (рис. 3). Установлено, что при увеличении содержания лигнина от 10 до 80 мас. \% площадь поверхности гелей проходит через максимум. Причем удельная поверхность гелей, полученных с использованием лиофильной сушки, во всех случаях выше, чем образцов, полученных с применением сверхкритической сушки.

Полученные результаты показали, что пористость таких материалов можно контролировать посредством соответствующего изменения состава реакционной смеси и режимов сушки.

Таблица 3. Характеристика лигнин-фенол-формальдегидных аэрогелей и криогелей с различным содержанием лигнина

\begin{tabular}{|c|c|c|c|c|c|c|}
\hline \multirow{2}{*}{$\begin{array}{c}\text { Содержание } \\
\text { лигнина (мас. \%) }\end{array}$} & \multicolumn{2}{|c|}{ Сверхкритическая сушка $\mathrm{CO}_{2}$} & \multicolumn{3}{|c|}{ Лиофильная сушка } \\
\cline { 2 - 7 } & $\rho_{b}, \mathrm{~g} / \mathrm{cm}^{3}$ & $\Phi, \%$ & $V_{p},\left(\mathrm{~cm}^{3} \mathrm{~g}^{-1}\right)$ & $\rho_{b}, \mathrm{~g} / \mathrm{cm}^{3}$ & $\Phi, \%$ & $V_{p},\left(\mathrm{~cm}^{3} \mathrm{~g}^{-1}\right)$ \\
\hline 80 & 0,23 & 84 & 3,63 & 0,28 & 80 & 2,86 \\
\hline 60 & 0,28 & 80 & 2,86 & 0,35 & 76 & 2,16 \\
\hline 40 & 0,34 & 76 & 2,23 & 0,49 & 66 & 1,35 \\
\hline 20 & 0,41 & 71 & 1,72 & 0,60 & 59 & 0,98 \\
\hline 10 & 0,89 & 36 & 0,41 & 0,72 & 50 & 0,70 \\
\hline
\end{tabular}

$\rho_{\mathrm{b}}$ - насыпная плотность, Ф - общая пористость, $\mathrm{V}_{\mathrm{p}}$ - общий объем пор. 


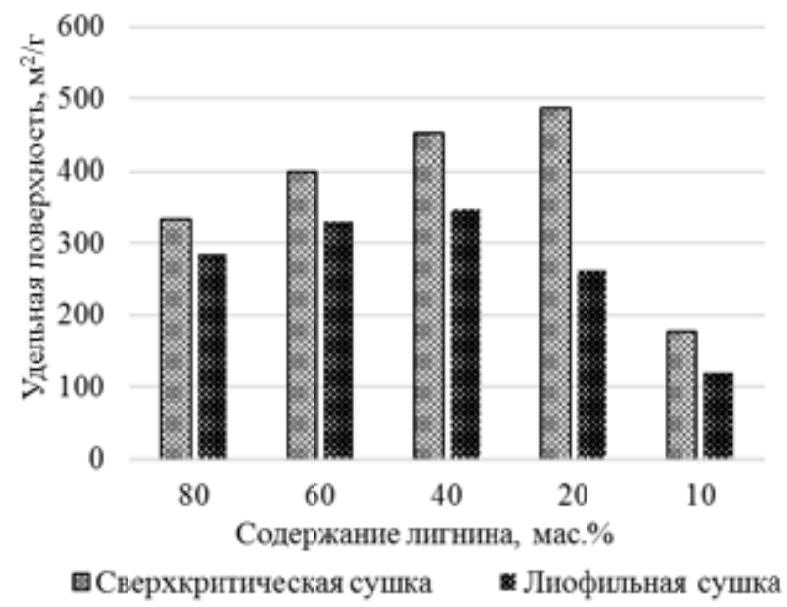

Рис. 3. Зависимость удельной площади поверхности органических аэро- и криогелей от содержания лигнина

Аэрогели на основе лигнина могут иметь пористость выше 80 \% и теплопроводность в диапазоне 0,040-0,045 Вт/(м·К), близкую к значениям теплопроводности коммерческих теплоизоляционных материалов, таких как пенополистиролы.

Исследование выполнено при финансовой поддержке Российского научного фонда (проект № 16-13-10326).

\section{Список литературы}

1. Lignin and Lignans: Advances in Chemistry. Eds. Heitner C., Dimmel D., Schmidt J. CRC Press: Taylor and Francis Group, 2010. 683 p.

2. Bio-based Polymers and Composites. Eds. R.P. Wool, X.S. Sun. London: Elsevier Academic Press, 2005. $640 \mathrm{p}$.

3. Lin Y., Tanaka S. Ethanol fermentation from biomass resources: current state and prospects. Applied Microbiology and Biotechnology 2006. Vol. 69(6), P. 627-642.

4. Azadi P., Inderwildi O.R., Farnood R., King D.A. Liquid fuels, hydrogen and chemicals from lignin: A critical review. Renewable and Sustainable Energy Reviews 2013. Vol. 21, P. 506-523.

5. Top Value-Added Chemicals from Biomass Volume II - Results of Screening for Potential Candidates from Biorefinery Lignin. Eds. J.E. Holladay, J.F. White, J.J. Bozell, D. Johnson. USA: Pacific Northwest National Laboratory, 2007. 87 p.

6. Saake B., Lehnen R. Lignin. Ullmann's Encyclopedia of Industrial Chemistry Weinheim, Germany: Wiley-VCH Verlag GmbH \& Co. KGaA, 2007. P. 21-36.

7. Singh A., Das K., Sharma D.K. Integrated process for production of xylose, furfural, and glucose from bagasse by two-step acid hydrolysis. Industrial \& Engineering Chemistry Product Research and Development 1984. Vol. 23(2), P. 257-262.

8. Bajpai P. Recent developments in cleaner production.Environmentally friendly production of pulp and paper. Hoboken, NJ. USA: John Wiley \& Sons, Inc.; 2010. P. 264-340. 
9. Rodríguez A., Jiménez L. Pulping with organic solvents other than alcohols. Afinidad 2008. Vol. 65(535), P. 188-196.

10. Pye E., Lora J. The Alcell process a proven alternative to kraftpulping. Tappi Journal 1991. Vol. 73(3), P.113-117.

11. Thring R., Vanderlaan M., Griffin S. Fractionation of Alcell lignin by sequential solvent extraction. Journal of Wood Chemistry and Technology 1996. Vol. 16(2), Vol. 139-154.

12. Lindner A., Wegener G. Characterization of lignins from organosolv pulping according to the organocell process PART 1. Elemental analysis, nonlignin portions and functional groups. Journal of Wood Chemistry and Technology 1988. Vol. 8(3), P. 323-340.

13. Patt R, Kordsachia O, Suttinger R. Pulp, in Ullmann's encyclopedia of industrial chemistry. Weinheim: Wiley-VCH Verlag GmbH \& Co. KGaA; 2012 pP. 476-539.

14. Кузнецова С.А., Яценкова О.В., Данилов В.Г., Калачева Г.С., Скворцова Г.П., Кузнецов Б.Н. Состав низкомолекулярных продуктов делигнификации древесины березы в среде «уксусная кислота-пероксид водорода-вода- $\mathrm{H}_{2} \mathrm{SO}_{4}$ ». Химия растительного сырья 2006. №2, С.1924. [Kuznetsova S.A., Yatsenkova O.V., Danilov V.G., Kalacheva G.S., Skvortsova G.P., Kuznetsov B.N. The composition of the delignification products with low molecular weight of birch wood in the «acetic acid-hydrogen peroxide-water-H2SO4» media. Chemistry of plant raw material 2006. №2, P. 19-24. (In Russ.)]

15. Гарынцева Н.В., Судакова И.Г., Кузнецов Б.Н. Изучение каталитической делигнификации древесины березы пероксидом водорода при атмосферном давлении. Журнал Сибирского федерального университета. Химия 2015. T. 8(3), C.422-429. [Garyntseva N.V., Sudakova I.G., Kuznetsov B.N. Study of Birch Wood Catalytic Delignification by Hydrogen Peroxide at Atmospheric Pressure. Journal of Siberian Federal University. Chemistry 2015. Vol. 8(3), P.422429. (In Russ.)]

16. Кузнецова С.А., Яценкова О.В., Данилов В.Г., Кузнецов Б.Н. Окислительная делигнификация древесины осины в среде уксусная кислота-пероксид водорода-вода в присутствии катализатора $\mathrm{H}_{2} \mathrm{MoO}_{4}$. Химия растительного сырья 2005. №4, С.35-39. [Kuznetsova S.A., Yatsenkova O.V., Danilov V.G., Kuznetsov B.N. Oxidative delignification of aspen wood in the acetic acid-hydrogen peroxide-water media in the presence of a catalyst $\mathrm{H}_{2} \mathrm{MoO}_{4}$. Chemistry of plant raw material 2005. №4, P. 35-39. (In Russ.)]

17. Villaverde J., Ligero P., Vega A. Formic and acetic acid as agents for a cleaner fractionation of Miscanthus x giganteus. Journal of Cleaner Production 2010. Vol. 18, P. 395-401.

18. Dapia S., Santos V., Parajo J. Study of formic acid as an agent for biomass fractionation. Biomass and Bioenergy 2002. Vol.22, P.213-221.

19. Quesada-Medina J., López-Cremades F.J., Olivares-Carrillo P. Organosolv extraction of lignin from hydrolyzed almond shells and application of the d-value theory. Bioresource Technology 2010. Vol. 101, P. 8252-8260.

20. Boeriu C.G., Fitigau F.I., Gosselink R.J.A., Frissen A.E., Stoutjesdijk J., Francisc P. Fractionation of five technical lignins by selective extraction in green solvents and characterization of isolated fractions. Industrial Crops and Products 2014. Vol. 62, P. 481-490.

21. Ильясов С.Г., Черкашин В.А., Сакович Г.В. Получение ацетонлигнина из мискантуса китайского. Ползуновский вестник 2013. №1, C.236-240. [Ilyasov S.G., Cherkashin V.A., Sakovich 
G.V. Acetolignin Preparation from Miscanthus Chinese. Polzunovsky Vestnik 2013. №1, P.236-240. (In Russ.)]

22. Zhang A., Lu F., Liu C., Sun R. Isolation and Characterization of Lignins from Eucalyptustereticornis. Journal of Agricultural and Food Chemistry 2010. Vol 58, P. 11287-11293.

23. Kosikova B., Poloin J. Isolation of lignin from spruce by acidolysis in dioxane. Wood Science and Technology 1973. Vol. 7 (4), P. 308-316.

24. Bauer S., Sorek H., Mitchell V.D., Ibáñez A.B., Wemmer D.E. Characterization of Miscanthus giganteus lignin isolated by ethanol organosolv process under reflux condition. Journal of Agricultural and Food Chemistry 2012. Vol. 60(33). P. 8203-8212.

25. Hussin M.H., Rahim A.A., Mohamad Ibrahim M.I., Brosse N. Physicochemical characterization of alkaline and ethanol organosolvlignins from oil palm (Elaeis guineensis) fronds as phenol substitutes for green material applications. Industrial Crops and Products 2013. Vol. 49, P. $23-32$.

26. Sammons R.J., Harper D.P., Labbé N., Bozell J.J., Elder T., Rials T.G. Characterization of organosolv lignins using thermal and FT-IR spectroscopic analysis. BioResources 2013. Vol. 8(2), P. 2752-2767.

27. Monteil-Rivera F., Phuong M., Ye M., Halasz A., Hawari J. Isolation and characterization of herbaceous lignins for applications in biomaterials. Industrial Crops and Products 2013. Vol. 41, P. 356-364.

28. Yáñez-S M., Matsuhiro B., Nuñez C., Pan S., Hubbell C.A., Sannigrahi P., Ragauskas A.J. Physicochemical characterization of ethanol organosolv lignin (EOL) from Eucalyptus globulus: Effect of extraction conditions on the molecular structure. Polymer Degradation and Stability 2014. Vol. 110, P. 184-194.

29. Santos P.S.B., Cademartori P.H.G., Prado R., Gatto D.A., Labidi J. Composition and structure of organosolv lignins from four eucalypt species. Wood Science and Technology 2014. Vol. 48(4), P. $873-885$.

30. Watkins D., Nuruddin M., Hosur M., Tcherbi-Narteh H., Jeelani S. Extraction and characterization of lignin from different biomass resources. Journal of Materials Research and Technology 2015. Vol. 4(5), P. 26-32.

31. Ravve A. Principles of Polymer Chemistry. New York, NY: Springer New York, 2012. 51-53 p.

32. Chanda M., Roy S.K. Characteristics of Polymers. CHAP. Plastics Technology Handbook, Fourth Edition Boca Raton, FL: Taylor \& Francis Group, 2012. P. 13-16.

33. Rogošić M., Mencer H.J., Gomzi Z. Polydispersity index and molecular weight distributions of polymers. European Polymer Journal 1996. Vol. 32(11), P. 1337-1344.

34. Tolbert A., Akinosho H., Khunsupat R., Naskar A.K., Ragauskas A.J. Characterization and analysis of the molecular weight of lignin for biorefining studies. Biofuels, Bioproducts and Biorefining 2014. Vol. 8(6), P. 836-856.

35. Brunow G., Brunow P.G. Methods to Reveal the Structure of Lignin. Lignin, Humic Substances and Coal / ed. Steinbüchel A., Hofrichter M. Weinheim, Germany: Wiley-VCH Verlag GmbH \& Co. KGaA, 2005. P. 89-99.

36. Gidh A. V., Decker S.R., Vinzant T.B., Himmel M.E., Williford C. Determination of lignin by size exclusion chromatography using multi angle laser light scattering. Journal of Chromatography A 2006. Vol. 1114(1), P. 102-110.

$$
-475-
$$


37. Reale S., Di Tullio A., Spreti N., De Angelis F. Mass spectrometry in the biosynthetic and structural investigation of lignins. Mass Spectrometry Reviews 2004. Vol. 23(2), P. 87-126.

38. De Hoffmann E., Stroobant V. Mass Spectrometry: Principles and Applications. Chichester: John Wiley \& Sons, Ltd, 2007. 504 p.

39. Himmel M.E., Oh K.K., Sopher D.W., Chum H.L. High-performance size exclusion chromatography of low-molecular-weight lignins and model compounds. Journal of Chromatography A 1983. Vol. 267(C), P. 249-265.

40. Himmel M.E., Tatsumoto K., Grohmann K., Johnson D.K., Chum H.L. Molecular weight distribution of aspen lignins from conventional gel permeation chromatography, universal calibration and sedimentation equilibrium. Journal of Chromatography A 1990. Vol. 498(C), P. 93-104.

41. Froment P., Pla F. Determinations of Average Molecular Weights and Molecular Weight Distributions of Lignin. ACS Symposium Series. Lignin 1989. Vol. 397(10), P. 134-143.

42. Gidh A. V., Decker S.R., See C.H., Himmel M.E., Williford C.W. Characterization of lignin using multi-angle laser light scattering and atomic force microscopy. Analytica Chimica Acta 2006. Vol. 555(2), P. 250-258.

43. Jönsson A.-S., Nordin A.-K., Wallberg O. Concentration and purification of lignin in hardwood kraft pulping liquor by ultrafiltration and nanofiltration. Chemical Engineering Research and Design 2008. Vol. 86(11), P. 1271-1280.

44. Hanton S.D. Mass Spectrometry of Polymers and Polymer Surfaces. Chemical Reviews 2001. Vol. 101(2), P. 527-570.

45. Siochi E.J., Ward T.C., Haney M.A., Mahn B. The absolute molecular weight distribution of hydroxypropylated lignins. Macromolecules 1990. Vol. 23(5), P. 1420-1429.

46. Mikame K., Funaoka M. Polymer Structure of Lignophenol II —Comparison of Molecular Morphology of Lignophenol and Conventional Lignins. Polymer Journal 2006. Vol. 38(6), P. 592596.

47. Glasser W.G., Barnett C.A., Muller P.C., Sarkanen K. V. The chemistry of several novel bioconversion lignins. Journal of Agricultural and Food Chemistry 1983. Vol. 31(5), P. 921-930.

48. Asikkala J., Tamminen T., Argyropoulos D.S. Accurate and Reproducible Determination of Lignin Molar Mass by Acetobromination. Journal of Agricultural and Food Chemistry 2012. Vol. 60(36), P. 8968-8973.

49. Zoia L., King A.W.T., Argyropoulos D.S. Molecular Weight Distributions and Linkages in Lignocellulosic Materials Derivatized from Ionic Liquid Media. Journal of Agricultural and Food Chemistry 2011. Vol. 59(3), P. 829-838.

50. Zhuang W. Lignins and Derivatives: GPC/SEC Analysis. CHAP. Encyclopedia of Chromatography, Third Edition CRC Press, 2009. P. 1359-1368.

51. Cathala B., Saake B., Faix O., Monties B. Association behaviour of lignins and lignin model compounds studied by multidetector size-exclusion chromatography. Journal of Chromatography A 2003. Vol. 1020(2), P. 229-239.

52. Majcherczyk A., Hüttermann A. Size-exclusion chromatography of lignin as ion-pair complex. Journal of Chromatography A 1997. Vol. 764(2), P. 183-191.

53. Chen F., Li J. Aqueous Gel Permeation Chromatographic Methods for Technical Lignins. Journal of Wood Chemistry and Technology 2000. Vol. 20(3), P. 265-276. 
54. Botaro V.R., Curvelo A.A. da S. Monodisperse lignin fractions as standards in size-exclusion analysis. Journal of Chromatography A 2009. Vol. 1216(18), P. 3802-3806.

55. Obiaga T.I., Wayman M. Improved calibration procedure for gel permeation chromatography of lignins. Journal of Applied Polymer Science 1974. Vol. 18(7), P. 1943-1952.

56. Kang S., Xiao L., Meng L., Zhang X., Sun R. Isolation and Structural Characterization of Lignin from Cotton Stalk Treated in an Ammonia Hydrothermal System. International Journal of Molecular Sciences 2012. Vol. 13(12), P. 15209-15226.

57. Wen J.-L., Xue B.-L., Xu F., Sun R.-C., Pinkert A. Unmasking the structural features and property of lignin from bamboo. Industrial Crops and Products 2013. Vol. 42 P. 332-343.

58. Zhou S., Liu L., Wang B., Xu F., Sun R. Microwave-enhanced extraction of lignin from birch in formic acid: Structural characterization and antioxidant activity study. Process Biochemistry 2012. Vol. 47(12), P. 1799-1806.

59. Brosse N., El Hage R., Chaouch M., Pétrissans M., Dumarçay S., Gérardin P. Investigation of the chemical modifications of beech wood lignin during heat treatment. Polymer Degradation and Stability 2010. Vol. 95(9), P. 1721-1726.

60. Guerra A., Mendonça R., Ferraz A. Molecular weight distribution of wood components extracted from Pinus taeda biotreated by Ceriporiopsis subvermispora. Enzyme and Microbial Technology 2003. Vol. 33(1), P. 12-18.

61. Sannigrahi P., Ragauskas A.J., Miller S.J. Lignin Structural Modifications Resulting from Ethanol Organosolv Treatment of Loblolly Pine. Energy \& Fuels 2010. Vol. 24(1), P. 683-689.

62. Cao S., Pu Y., Studer M., Wyman C., Ragauskas A.J. Chemical transformations of Populus trichocarpa during dilute acid pretreatment. RSC Advances 2012. Vol. 2(29), P. 10925.

63. Hu G., Cateto C., Pu Y., Samuel R., Ragauskas A.J. Structural Characterization of Switchgrass Lignin after Ethanol Organosolv Pretreatment. Energy \& Fuels 2012. Vol. 26(1), P. 740-745.

64. Moon S.-J., Eom I.-Y., Kim J.-Y., Kim T.-S., Lee S.M., Choi I.-G., Choi J.W. Characterization of lignin-rich residues remaining after continuous super-critical water hydrolysis of poplar wood (Populus albaglandulosa) for conversion to fermentable sugars. Bioresource Technology 2011. Vol. 102(10), P. 5912-5916.

65. Xiao L.-P., Shi Z.-J., Xu F., Sun R.-C. Characterization of Lignins Isolated with Alkaline Ethanol from the Hydrothermal Pretreated Tamarix ramosissima. BioEnergy Research 2013. Vol. 6(2), P. 519-532.

66. Zhou H., Zhu J.Y., Luo X., Leu S.-Y., Wu X., Gleisner R., Dien B.S., Hector R.E., et al. Bioconversion of Beetle-Killed Lodgepole Pine Using SPORL: Process Scale-up Design, Lignin Coproduct, and High Solids Fermentation without Detoxification. Industrial \& Engineering Chemistry Research 2013. Vol. 52(45), P. 16057-16065.

67. Xu F., Sun J.-X., Sun R., Fowler P., Baird M.S. Comparative study of organosolv lignins from wheat straw. Industrial Crops and Products 2006. Vol. 23(2), P. 180-193.

68. Alvarez-Vasco C., Ma R., Quintero M., Guo M., Geleynse S., Ramasamy K.K., Wolcott M., Zhang X. Unique low-molecular-weight lignin with high purity extracted from wood by deep eutectic solvents (DES): a source of lignin for valorization. Green Chemistry 2016. Vol. 18(19), P. 5133-5141. 
69. Li M.-F., Sun S.-N., Xu F., Sun R.-C. Formic acid based organosolv pulping of bamboo (Phyllostachys acuta): Comparative characterization of the dissolved lignins with milled wood lignin. Chemical Engineering Journal 2012. Vol. 179, P. 80-89.

70. Kuznetsov B.N., Sudakova I.G., Celzard A., Garyntseva N.V., Ivanchenko N.M., Petrov A.V. Binding Properties of Lignins Obtained at Oxidative Catalytic Delignification of Wood and Straw. Journal of Siberian Federal University. Chemistry 2011. Vol. 4(1), P. 3-10.

71. Гарынцева Н.В., Судакова И.Г., Кузнецов Б.Н. Свойства энтеросорбентов, полученных из уксуснокислотных лигнинов древесины пихты, осины и березы. Журнал Сибирского федерального университета. Химия 2011. Т. 4(2), C.121-126. [Garyntseva N.V., Sudakova I.G., Kuznetsov B.N. Properties of Enterosorbents Obtained from Acetic Acid Lignins of Abies, Aspen and Birch Wood. Journal of Siberian Federal University. Chemistry 2011. Vol. 4(2), P.121-126. (In Russ.)]

72. Кузнецов Б.Н., Чесноков Н.В., Иванов И.П., Веприкова Е.В., Иванченко Н.М. Методы получения пористых материалов из лигнина и древесной коры (обзор). Журнал Сибирского федерального университета. Химия 2015. T. 8(2), C.232-255. [Kuznetsov B.N., Chesnokov N.V., Ivanov I.P., Veprikova E.V., Ivanchenko N.M. Methods of Porous Materials Obtaining from Lignin and Wood Bark. Journal of Siberian Federal University. Chemistry 2015. Vol. 8(2), P.232-255. (In Russ.)]

73. Grishechko L.I., Amaral-Labat G., Szczurek A., Fierro V., Kuznetsov B.N., Pizzi A., Celzard A. New tannin - lignin aerogels. Industrial Crops \& Products 2013. Vol. 41, P. 347-355

74. Yang H., Yan R., Chen H., Lee D., Zheng C. Characteristics of hemicellulose, cellulose and lignin pyrolysis. Fuel 2007. Vol. 86, P. 1781-1788.

75. Choi H., Meier D., Windt M. Rapid screening of catalytic pyrolysis reactions oforganosolvlignins with the vTI-mini fast pyrolyzer. Environmental Progress\& Sustainable Energy 2012. Vol. 31, P.240-144.

76. Cho J., Chu S., Dauenhauer P., Huber G. Kinetics and reaction chemistry for slow pyrolysis of enzymatic hydrolysis lignin and organosolv extracted lignin derived from maplewood. Green Chemistry 2012. Vol. 14, P.428-439.

77. Beis S., Mukkamala S., Hill N., Joseph J., Baker C,. Jensen B., et al. Fast Pyrolysis of Lignins. Bioresources 2010. Vol. 5(3), P. 1408-1424.

78. Evans R., Milne T., Soltys M. Direct mass-spectrometric studies of the pyrolysis of carbonaceous fuels. Journal of Analytical and Applied Pyrolysis 1986. Vol .9, P. 207-236.

79. Jankovic B. The comparative kinetic analysis of acetocell and lignoboost lignin pyrolysis: the estimation of the distributed reactivity models. Bioresource Technology 2011. Vol. 102, P.97639771.

80. Ferdous D., Dalai A., Bej S., Thring R. Pyrolysis of lignins: experimental and kinetics studies. Energy \& Fuels 2002. Vol. 16, P.1405-1412.

81. Patwardhan P., Brown R., Shanks B. Understanding the fast pyrolysis of lignin. ChemSusChem 2011. Vol. 4, P.1629-1636.

82. Jiang G., Nowakowski D., Bridgwater A. Effect of the temperature on the composition of lignin pyrolysis products. Energy \& Fuels 2010. Vol. 24. P.4470-4475.

83. Wahyudiono M., Sasaki G.M. Recovery of phenolic compounds through the decomposition of lignin in near and supercritical water. Chemical Engineering and Processing 2008. Vol. 47. P.16091619. 
84. Saisu M., Sato T., Watanabe M., Adschiri T., Arai K. Conversion of lignin with supercritical water-phenol mixtures. Energy \& Fuels 2003. Vol. 17, 922-928.

85. Karagoz S., Bhaskar T., Muto A., Sakata Y. Comparative studies of oil compositions produced from sawdust, rice husk, lignin and cellulose by hydrothermal treatment. Fuel 2005. Vol. 84, P.875-884.

86. Zhang B., Huang H., Ramaswamy S. Reaction kinetics of the hydrothermal treatment of lignin. Applied Biochemistry and Biotechnology 2008. Vol. 147, Vol. 119-131.

87. Toledano A., Serrano L., Labidi J. Organosolv lignin depolymerization with different base catalysts. Journal of Chemical Technology \& Biotechnology 2012. Vol. 87. P.1593-1599.

88. Roberts V., Stein V., Reiner T., Lemonidou A., Li X., Lercher J. Towards quantitative catalytic lignin depolymerization. Chemistry - A European Journal 2011. Vol. 17, P. 5939-5948.

89. Vigneault A., Johnson D., Chornet E.. Base-catalyzed depolymerization of lignin: separation of monomers. Canadian Journal of Chemical Engineering 2007. Vol. 85, P.906-916.

90. Heitz M., Wu G., Lapointe J. Hydrolytic depolymerization of a steam explosion lignin. Journal of Wood Chemistry and Technology 1995. Vol. 15, P. 515-528.

91. Matsumura Y., Sasaki M., Okuda K., Takami S., Ohara S., Umetsu M., et al. Supercritical water treatment of biomass for energy and material recovery. Combustion Science and Technology 2006. Vol. 178. P.509-536.

92. Okuda K., Man X., Umetsu M., Takami S., Adschiri T.. Efficient conversion of lignin into single chemical species by solvothermal reaction in water-p-cresol solvent. Journal of Physics: Condensed Matter 2004. Vol. 16, P.1325-1330.

93. Yoshikawa T., Yagi T., Shinohara S., Fukunaga T., Nakasaka Y., Tago T., et al. Production of phenols from lignin viadepolymerization and catalytic cracking. Fuel Processing Technology 2013. Vol. 108, P. 69-75.

94. Miller J., Evans L., Littlewolf A., Trudell D. Batch microreactor studies of lignin and lignin model compound depolymerization by bases in alcohol solvents. Fuel 1999. Vol. 78, P. 1363-1366.

95. Tang Z., Zhang Y., Guo Q. Catalytic hydrocracking of pyrolytic lignin to liquid fuel in supercritical ethanol. Industrial \& Engineering Chemistry Research 2010. Vol. 49, P. 2040-2046.

96. Nagy M., David K., Britovsek G., Ragauskas A. Catalytic hydrogenolysis of ethanol organosolv lignin. Holzforschung 2009, Vol. 63, P.513-520.

97. Cheng S., Wilks C., Yuan Z., Leitch M,. Xu C. Hydrothermal degradation of alkali lignin to bio-phenolic compounds in sub/supercritical ethanol and water-ethanol co-solvent. Polymer Degradation and Stability 2012. Vol. 97, P.839-848.

98. Ильясов С.Г., Черкашин В.А. Деполимеризация ацетонлигнина в этаноле. Южносибирский научный вестник 2014. T. 4(8), C.18-20. [Ilyasov S.G., Cherkashin V.A. Acetolignin depolymerization in ethanol. South-Siberian Scientific Bulletin 2014. Vol. 4(8), P. 18-20. (In Russ.)]

99. Tsujino J., Kawamoto H., Saka S. Reactivity of lignin in supercritical methanol studied with various lignin model compounds. Wood Science and Technology 2003. Vol. 37, P. 299-307.

100. Barta K., Matson T., Fettig M., Scott S., Iretskii A., Ford P. Catalytic disassembly of an organosolv lignin via hydrogen transfer from supercritical methanol. Green Chemistry 2010. Vol. 12. P.1640-1647. 
101. Ильясов С.Г., Черкашин В.А., Сакович Г.В. Деполимеризация ацетонлигнина метанолом в сверхкритических условиях. Ползуновский вестник 2013. №3, C.159-162. [Ilyasov S.G., Cherkashin V.A., Sakovich G.V. Acetolignin depolymerization by methanol in supercritical conditions. Polzunovsky Vestnik 2013. №3, P.159-162. (In Russ.)]

102. Gosselink R., Teunissen W., Dam J., Jong E., Gellerstedt G., Scott E., et al. Lignin depolymerisation in supercritical carbon dioxide/acetone/water fluid for the production of aromatic chemicals. Bioresource Technology 2012. Vol. 106. P. 173-177.

103. Шарыпов В.И., Кузнецов Б.Н., Яковлев В.А., Береговцова Н.Г., Барышников С.В., Дьякович Л., Пинель К. Состав жидких продуктов конверсии ацетонлигнина в сверхкритическом бутаноле в присутствии катализаторов $\mathrm{NiCu} / \mathrm{SiO}_{2}$. Журнал Сибирского федерального университета. Химия 2015. T. 8(3), C. 465-475. [Sharypov V.I., Kuznetsov B.N., Yakovlev V.A., Beregovtsova N.G., Baryshnikov S.V., Djakovitch L., Pinel C. Composition of Liquid Products of Acetonlignin Conversion Over $\mathrm{NiCu} / \mathrm{SiO}_{2}$ Catalysts in Supercritical Butanol. Journal of Siberian Federal University. Chemistry 2015. Vol. 8(3), P. 465-475. (In Russ.)]

104. Kleinert M., Barth T. Towards a lignincellulosic biorefinery: direct one-step conversion of lignin to hydrogen-enriched biofuel. Energy \& Fuels 2008. Vol. 22, P. 1371-1379.

105. Xu W., Miller S., Agrawal P., Jones C. Depolymerization and hydrodeoxygenation of switchgrass lignin with formic acid. ChemSusChem 2012 Vol. 5, P.667-675.

106. Zakzeski J., Bruijnincx P.C.A., Jongerius A.L., Weekhuysen B.M. The Catalytic Valorization of Lignin for the Production of Renewable Chemicals. Chemical Reviews 2010. Vol. 110, P. 35523599 .

107. Mullen Ch.A., Boateng A.A. Catalytic pyrolysis-GC/MS of lignin from several sources. Fuel Processing Technology 2010. Vol. 91, P. 1446-1448.

108. Maa Z., Troussarda E., Bokhovena J.A. Controlling the selectivity to chemicals from lignin via catalytic fast pyrolysis. Applied Catalysis A: General 2012. Vol. 423-424, P. 130-136.

109. Ibanez M., Valle B., Bilbao J., Gayubo A.G., Castano P. Efect of operating conditions on the coke nature and HZSM-5 catalysts deactivation in the transformation of crude bio-oil into hydrocarbons. Catalysis Today 2012. Vol. 195, P. 106-113.

110. Zhao C., Kou Y., Lemonidou A.A., Li X., Lercher J.A. Catalytic depolymerization and deoxy-genation of lignin. Angewandte Chemie International Edition 2009. Vol. 48, P. 3987-3990.

111. Jacson M., Compton D., Boateng A. Creening heterogeneous catalysts for the pyrolysis of lignin. Journal of Analytical and Applied pyrolysis 2009. Vol. 85, P. 226-230.

112. Yoshikawa T., Na-Ranong D., Tago T., Masuda T. Oxidative cracking of aromatic compounds related to lignin constituents with steam using $\mathrm{ZrO}_{2}-\mathrm{Al}_{2} \mathrm{O}_{3}-\mathrm{FeOX}$ catalyst. Journal of the Japan Petroleum Institute 2010. Vol. 53, P.178-183.

113. Funai S., Satoh Y., Satoh Y., Tajima K., Tago T., Masuda T. Development of a new conversion process consisting of hydrothermal treatment and catalytic reaction using $\mathrm{ZrO}_{2}-\mathrm{FeOX}$ catalyst to convert fermentation residue into useful chemicals. Topics in Catalysis 2010. Vol. 53, P. 654-658.

114. Na-Ranong D., Yuangsaward R., Tago T., Masuda T. Recovery of useful chemicals from oil palm shell-derived oil using zirconia supporting iron oxide catalysts. Korean Journal of Chemical Engineering 2008. Vol. 25, P. 426-430. 
115. Masuda T., Kondo Y., Miwa M., Shimotori Y., Mukai S.R., Hashimoto K., Takano M., Kawasaki S., Yoshida S. Recovery of useful hydrocarbons from oil palm waste using $\mathrm{ZrO}_{2}$ supporting FeOOH catalyst. Chemical Engineering Science 2001. Vol. 56, P. 897-904.

116. Боголицын К.Г. Перспективы применения сверхкритических флюидных технологий в химии растительного сырья. Сверхкритические флюиды: Теория и практика 2007. Т.2. №1, C.16-27. [Bogolitsyn K.G. Prospects for the use of supercritical fluid technology in vegetable raw materials chemistry. Supercritical Fluids: Theory and Practice 2007. Vol. 2(1), P. 16-27. (In Russ.)]

117. Kleinert M., Barth T. Phenols from Lignin. Chemical Engineering and Technology 2008. Vol. 31, P. 736-745.

118. Kleinert M., Barth T. Towards a Lignincellulosic Biorefinery: Direct One-Step Conversion of Lignin to Hydrogen-Enriched Biofuel. Energy \& Fuels 2008. Vol. 22, P.1371-1379.

119. Miller J.E., Evans L., Littlewolf A., Trudell D.E. Batch microreactor studies of lignin and lignin model compound depolymerization by bases in alcohol solvents. Fuel 1999. Vol. 78, P.13621366.

120. Kuznetsov B.N., Sharypov V.I., Chesnokov N.V., Beregovtsova N.G., Baryshnikov S.V., Lavrenov A.V., Vosmerikov A.V., Agabekov V.E. Lignin conversion in supercritical ethanol in the presence of solid acid catalysts. Kinetics and Catalysis 2015. Vol. 56(4), P. 434-441.

121. Feteira A., Reichmann K. Sol-Gel Processing for Conventional and Alternative Energy. 2012. $965 \mathrm{p}$.

122. Celzard A., Fierro V., Amaral-Labat G. Adsorption by Carbon Gels. In: Tascon JMD editor, 5. Novel Carbon Adsorbents. Elsevier; Oxford; 2012, P. 207-244.

123. Meena A.K., Mishra G.K., Rai P.K., Rajagopal C., Nagar P.N. Removal of heavy metal ions from aqueous solutions using carbon aerogel as an adsorbent. Journal of Hazardous Materials 2005. Vol. 122(1-2), P. 161-170.

124. Lee Y.J., Jung J.C., Park S., Seo J.G., Baeck S.H., Yoon J.R., Yi J., Song I.K. Preparation and characterization of metal-doped carbon aerogel for supercapacitor. Current Applied Physics 2010. Vol. 10(3), P. 947-951.

125. Aegerter M. A., Leventis N., Koebel M. M. Aerogels Handbook. Advances in sol-gel derived for materials and technologies. New York: Springer-Verlag, 2011. 932 p.

126. Chen F., Xu M., Wang L., Li J. Preparation and characterization of organic aerogels from a lignin - resorcinol - formaldehyde copolymer. BioResources 2011. Vol. 6(2), P. 1262-1272.

127. Chen F., Li J. Synthesis and Structural Characteristics of Organic Aerogels with Different Content of Lignin. Advanced Materials Research 2010. Vol. 113-116 P. 1837-1840.

128. Raman S.P., Gurikov P., Smirnova I. Hybrid alginate based aerogels by carbon dioxide induced gelation: Novel technique for multiple applications. Journal of Supercritical Fluids 2015. Vol. 106, P. 23-33.

129. Sakeena A., Marta Q., Alexandre M., Pavel B., Raman G.S.P., Smirnova I., Rita A., Reis D.R.L. Novel non-cytotoxic alginate-lignin hybrid aerogels as scaffolds for tissue engineering. The Journal of Supercritical Fluids 2015. Vol. 105 P. 1-8.

130. Wang C., Xiong Y., Fan B., Yao Q., Wang H., Jin C., Sun Q. Cellulose as an adhesion agent for the synthesis of lignin aerogel with strong mechanical performance, Sound-absorption and thermal Insulation. Scientific Reports 2016. Vol. 6, P. 32383.

$$
-481-
$$


131. Xu X., Zhou J., Nagaraju D.H., Jiang L., Marinov V.R., Lubineau G., Alshareef H.N., Oh M. Flexible, highly graphitized carbon aerogels based on bacterial cellulose/lignin: Catalyst-free synthesis and its application in energy storage devices. Advanced Functional Materials 2015. Vol. 25(21), P. 3193-3202.

132. Viggiano R. P., Schiraldi D. A. Fabrication and mechanical characterization of lignin-based aerogels. Green Materials 2015. Vol. 2(GMAT3), P. 153-158.

133. Yang Y., Deng Y., Tong Z., Wang C. Renewable Lignin-Based Xerogels with Self-Cleaning Properties and Superhydrophobicity. ACS Sustainable Chemistry \& Engineering 2014. Vol. 2 (7), P. 1729-1733.

134. Castro C.D., Quintana G.C. Mixture Design Approach on the Physical Properties of LigninResorcinol-Formaldehyde Xerogels. International Journal of Polymer Science 2015. Vol. 2015.

135. Perez-cantu L., Liebner F., Smirnova I. Preparation of aerogels from wheat straw lignin by cross-linking with oligo(alkylene glycol)- $\alpha, \omega$-diglycidyl ethers. Microporous and Mesoporous Materials 2014. Vol. 195 P. 303-310.

136. Forgacz C., Birot M., Deleuze H. Synthesis of porous emulsion-templated monoliths from a pulp mill by-product. Journal of Applied Polymer Science 2013. Vol. 129(5), P. 2606-2613.

137. Forgacz C., Caubet S., Le Guer Y., Grassl B., Omari K. El, Birot M., Deleuze H. Synthesis of Porous Emulsion-Templated Monoliths Using a Low-Energy Emulsification Batch Mixer. Journal of Polymers and the Environment 2013. Vol. 21(3), P. 683-691.

138. Grishechko L.I., Amaral-labat G., Szczurek A., Fierro V., Kuznetsov B.N., Celzard A. Lignin - phenol - formaldehyde aerogels and cryogels. Microporous and Mesoporous Materials 2013. Vol. 168 P. 19-29. 